\title{
Elucidation of Melanogenesis Cascade for Identifying Pathophysiology and Therapeutic Approach of Pigmentary Disorders and Melanoma
}

\author{
Tokimasa Hida ${ }^{1}$, Takafumi Kamiya ${ }^{1}{ }^{\circledR}$, Akinori Kawakami ${ }^{2}$, Jiro Ogino ${ }^{3}$, Hitoshi Sohma ${ }^{4}{ }^{\circledR}$, \\ Hisashi Uhara ${ }^{1}{ }^{1}$ and Kowichi Jimbow ${ }^{5, *}$ \\ 1 Department of Dermatology, Sapporo Medical University School of Medicine, Sapporo 060-8543, Hokkaido, \\ Japan; hidat@sapmed.ac.jp (T.H.); kamitaka@sapmed.ac.jp (T.K.); uharah@sapmed.ac.jp (H.U.) \\ 2 Cutaneous Biology Research Center, Department of Dermatology, Massachusetts General Hospital, \\ Harvard Medical School, Charlestown, MA 02129, USA; akawakami1@mgh.harvard.edu \\ 3 Department of Pathology, JR Sapporo Hospital, Sapporo 060-0033, Hokkaido, Japan; jiroogino@gmail.com \\ 4 Department of Biomedical Engineering, Sapporo Medical University School of Medicine, Sapporo 060-8556, \\ Hokkaido, Japan; sohma@sapmed.ac.jp \\ 5 Institute of Dermatology \& Cutaneous Sciences, Sapporo 060-0042, Hokkaido, Japan \\ * Correspondence: jimbow@sapmed.ac.jp; Tel.: +81-11-887-8266
}

Received: 2 August 2020; Accepted: 22 August 2020; Published: 25 August 2020

\begin{abstract}
Melanogenesis is the biological and biochemical process of melanin and melanosome biosynthesis. Melanin is formed by enzymic reactions of tyrosinase family proteins that convert tyrosine to form brown-black eumelanin and yellow-red pheomelanin within melanosomal compartments in melanocytes, following the cascades of events interacting with a series of autocrine and paracrine signals. Fully melanized melanosomes are delivered to keratinocytes of the skin and hair. The symbiotic relation of a melanocyte and an associated pool of keratinocytes is called epidermal melanin unit (EMU). Microphthalmia-associated transcription factor (MITF) plays a vital role in melanocyte development and differentiation. MITF regulates expression of numerous pigmentation genes for promoting melanocyte differentiation, as well as fundamental genes for maintaining cell homeostasis. Diseases involving alterations of EMU show various forms of pigmentation phenotypes. This review introduces four major topics of melanogenesis cascade that include (1) melanocyte development and differentiation, (2) melanogenesis and intracellular trafficking for melanosome biosynthesis, (3) melanin pigmentation and pigment-type switching, and (4) development of a novel therapeutic approach for malignant melanoma by elucidation of melanogenesis cascade.
\end{abstract}

Keywords: melanogenesis; tyrosinase; tyrosinase related protein (TYRP); vesicular transport; melanosome; eumelanin; pheomelanin; pigment-type switching; hypomelanosis; melanoma

\section{Introduction}

Melanin determines colors of our skin, eyes, and hair and protects the skin from sunlight exposure. Melanin is a biopolymer synthesized within pigment cells, melanocytes, and packaged in the specialized lysosome-related organelles called melanosomes. The biological and biochemical pathway of melanin biosynthesis is known as melanogenesis. Melanogenesis is an enzymatic reaction in which melanin-forming tyrosinase family proteins convert an amino acid, tyrosine, to form brown-black eumelanin and yellow-red pheomelanin in melanocytes [1]. Melanogenesis involves a series of paracrine and autocrine signals, beginning with activation of the cyclic adenosine monophosphate (cAMP)/cAMP response element-binding protein (CREB)-signaling pathway in melanocytes, mainly by a G-protein-coupled receptor, melanocortin 1 receptor (MC1R) in response to its ligands, mainly 
alpha-melanocyte-stimulating hormone ( $\alpha$-MSH). Activated MC1R increases intracellular cAMP, which in turn activates CREB and eventually stimulates transcription of microphthalmia-associated transcription factor (MITF), a master transcription factor of melanocyte development and differentiation. MITF activates expression of key melanin-forming genes including genes for tyrosinase family enzymes and the melanosomal structural matrix protein PMEL. MC1R loss-of-function variants result in fair-colored skin and hair [2].

Tyrosinase is a glycoprotein that acts as the major player of this melanogenesis pathway. Its glycosylation process is regulated by a number of molecular chaperons, including calnexin in the endoplasmic reticulum [3,4]. Vesicular transport occurs to carry tyrosinase and its related proteins from the trans-Golgi network to melanosomal compartments. In addition, small molecular materials that may be directly or indirectly involved in melanogenesis accumulate on the cell surface of melanocytes and are endocytosed through vesicular transport to melanosomal compartments [5]. A large number of transporters, such as small GTP-binding proteins, adaptor proteins, and phosphoinositide-3-kinase (PI3K) are involved in vesicular transport for melanosome maturation [6-10]. Thus, the sorting motifs of tyrosinase family enzymes and other melanosomal proteins are unique and complex. Once biosynthesis of eumelanin or pheomelanin is completed, eumelanogenic melanosomes become ellipsoidal granules with specific lattice-like internal structures, while pheomelanogenic melanosomes take oval forms with many granular internal substructures. The mature melanosomes move along dendritic processes and are transferred to surrounding keratinocytes [1]. Fully melanized melanosomes are finally delivered to keratinocytes throughout the skin. The symbiotic relation between a melanocyte and an associated pool of keratinocytes is called an epidermal melanin unit (EMU). Diseases involving alterations of EMU show pigmentation phenotypes such as oculocutaneous albinism and Hermansky-Pudlak syndrome [11].

This review discusses certain aspects of current progresses in major pathways of melanogenesis cascade which include (1) melanocyte development and differentiation, (2) melanosome biosynthesis and intracellular trafficking, and (3) melanin pigment-type switching, and then introduces the possibility of applying the knowledge of melanogenesis cascade for elucidating the pathophysiology of pigmentary disorders and developing a novel therapeutic approach for malignant neoplasia of melanocytes, melanoma [12].

\section{Melanocyte Development and Differentiation}

\subsection{Melanocyte Development from Neural Crest}

Neural crest cells are migratory multipotent cells derived from the dorsal neural tube during embryonic development that give rise to neurons, glial cells, bone and cartilage cells, and melanocytes. The "classic" melanocyte precursors, melanoblasts, migrate in the dorsolateral pathway to reach the basal layer of epidermis and hair follicles [13]. Adameyko et al. found multipotent Schwann cell precursors to be a source of melanocytes [14]. Schwann cell precursors produce the majority of body and extremity melanocytes [14], while both "classic" melanocyte precursors and Schwann cell precursors produce cranial melanocytes [15]. Apart from the skin and hair, melanocytes exist in the eye, inner ear, and internal organs such as lung, heart, and aorta. Coat color mutants in mice and other species (e.g., Kit, Ednrb, and Edn3) led researchers to identify genes involved in melanocyte development [16-18]. Melanocyte stem cells localize in the bulge region of hair follicles and produce epidermal and hair follicle melanocytes [19]. Reactive oxygen species induced by genotoxic stresses and pain-induced adrenaline cause hair graying by making melanocyte stem cells differentiate [20-22].

\subsection{A Master Role of MITF in Melanocyte Development and Differentiation}

MITF belongs to the basic helix-loop-helix leucine zipper transcription factor family and its mutations in mice cause coat color dilutions and melanocyte loss [23-25]. In humans, MITF mutations cause Waardenburg syndrome type 2A, which phenocopies melanocyte loss [26]. MITF binds a 
consensus DNA binding motif E-box (CA[C/T]GTG) and regulates gene transcription by making homodimers or heterodimers with other MiT family members TFE3 and TFEB [27]. KIT increases both transcriptional activity and degradation of MITF by phosphorylating MITF at serine 73 and serine 409 [28]. MITF turns on melanogenesis by activating transcription of pigment genes such as tyrosinase (TYR), tyrosinase-related protein 1 (TYRP1), dopachrome tautomerase (DCT), and PMEL [29-31].

The cAMP/CREB- and Wnt-signaling pathways, PAX3, and SOX10 activate transcription of the melanocyte specific MITF-M isoform [32-35]. The cAMP/CREB pathway plays a key role in sun tanning and determining skin and hair colors. UV irradiation damages DNA and activates TP53, which induces proopiomelanocortin (POMC) expression in keratinocytes [36]. Secreted $\alpha$-MSH cleaved from POMC binds MC1R on melanocytes, induces MITF, and activates melanogenesis. MC1R loss-of-function variants result in fair-colored skin and hair.

CREB activation rescues pigmentation from MC1R loss-of-function polymorphisms. Forskolin, which increases a cAMP level by activating adenylate cyclase, made the fair-colored skin of $M c 1 r$ mutant mice darker and protected skin from UV light. In addition, salt-inducible kinase (SIK) inhibitors made not only Mc1r mutant mouse skin but also fair-colored human skin darker by activating CREB through translocating CREB co-activator CRTC into the nucleus [37,38] (Figure 1). Although detailed mechanisms remain unclear, prohibitin 2-light chain 3-CREB axis activated melanogenesis through increasing MITF-M expression in melanocytes and melanoma cell lines [39,40]. Melanogenin and its analogues, which activate this pathway, could also rescue pigmentation. These findings suggest that we could modulate genetically defined melanogenesis activity.

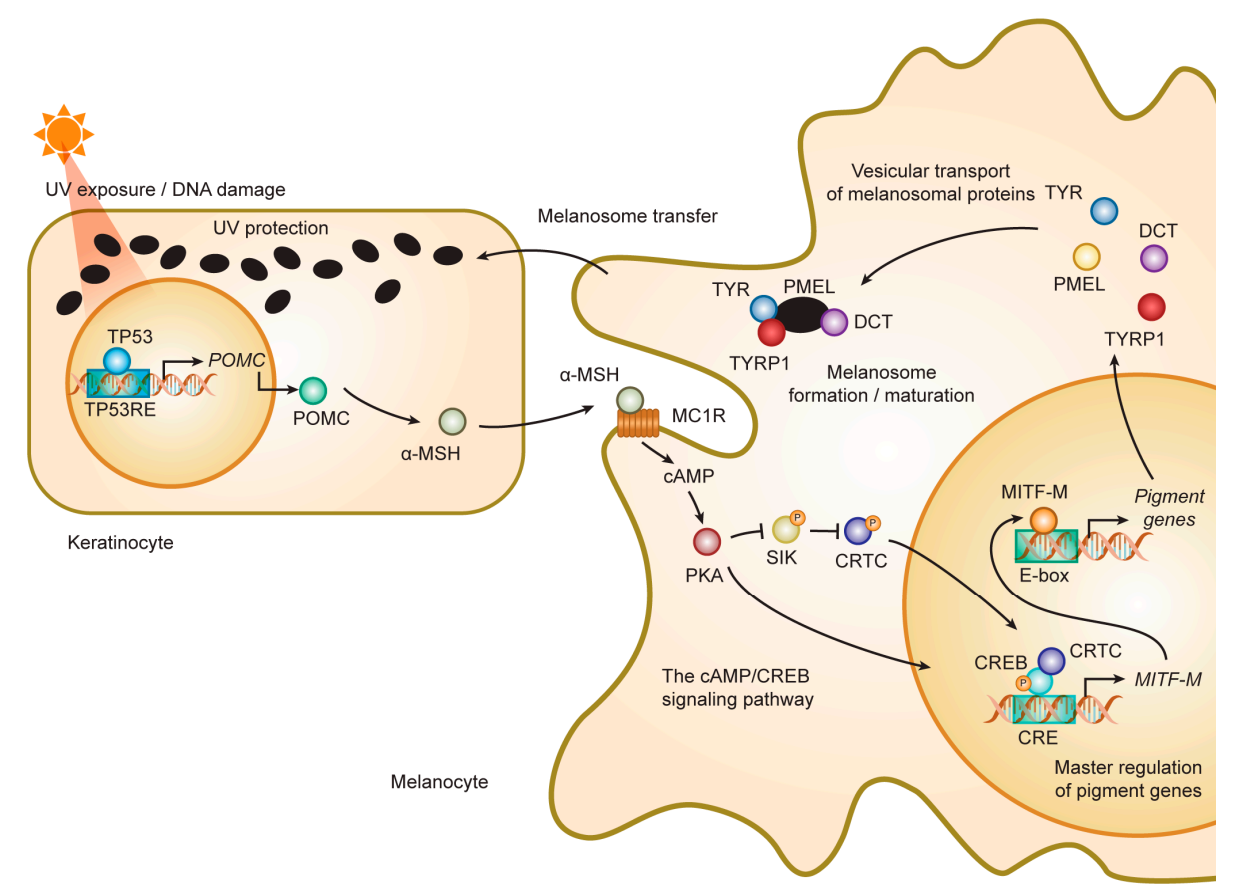

Figure 1. Role of MITF in melanogenesis cascade in human skin. The cascade of melanogenesis consists of the interaction between a melanocyte and an associated pool of keratinocytes, called epidermal melanin unit. MITF plays a master role in the cascade process for the activation/differentiation of the melanocyte followed by the induction of melanogenesis cascade such as during UV-induced tanning reaction. UV damages DNA in keratinocytes. DNA damage activates TP53 that initiates the transcription of POMC. POMC is cleaved into peptides including $\alpha-\mathrm{MSH}$. $\alpha$-MSH secreted from keratinocytes binds MC1R and increases CAMP in melanocytes. PKA activated by cAMP activates CREB transcriptional activity in two ways: (i) Phosphorylate CREB; (ii) inhibiting SIK, a negative regulator of CREB co-activator CRTCs, by phosphorylating SIK. CREB activates the transcription of MITF-M. MITF-M activates the transcription of pigment genes including TYR, TYRP1, DCT, and PMEL. 
Melanosomal proteins are delivered to melanosomes. Matured melanosomes are transferred from melanocytes to keratinocytes and accumulate on the nucleus to block UV light. Abbreviations: $\alpha$-MSH, alpha-melanocyte-stimulating hormone; cAMP, cyclic adenosine monophosphate; CRE, cAMP response element; CREB, CRE-binding protein; CRTC, CREB-regulated transcriptional coactivator; MC1R, melanocortin 1 receptor; MITF, microphthalmia-associated transcription factor; SIK, salt-inducible kinase; PKA, protein kinase A; POMC, proopiomelanocortin; TYR, tyrosinase; TYRP1, tyrosinase-related protein 1.

\section{Melanogenesis and Intracellular Trafficking for Melanosome Biosynthesis}

\subsection{Formation and Maturation of Melanosomes}

Melanosomes have four maturation stages characterized by unique shapes and amounts of melanin pigments. In stage I, the melanosome structure is similar to the vacuolar domain of early/late endosomes, presenting as intralumenal vesicles with the deposition of fibrils composed predominantly of the pigment cell-specific protein PMEL (also known as the silver locus product, PMel17), an integral membrane protein [41-43]. PMEL is responsible for the ellipsoidal shape of melanosomes. In stage II, the ellipsoidal form of melanosomes is morphologically changed due to reorganization of the fibrils after cleavage of PMEL and release of the M $\alpha$ moiety, which is formed from the M $\beta$ membrane fragment. Stage I and stage II melanosomes are called premelanosomes, which lack deposits of melanin; it is deposited in PMEL fibrils of stage III melanosomes. Fully melanized melanosomes are the characteristic of stage IV. During stages II to IV, melanogenesis proteins including tyrosinase, TYRP1, and TYRP2/DCT are delivered to melanosomes [44,45] (Figure 2).

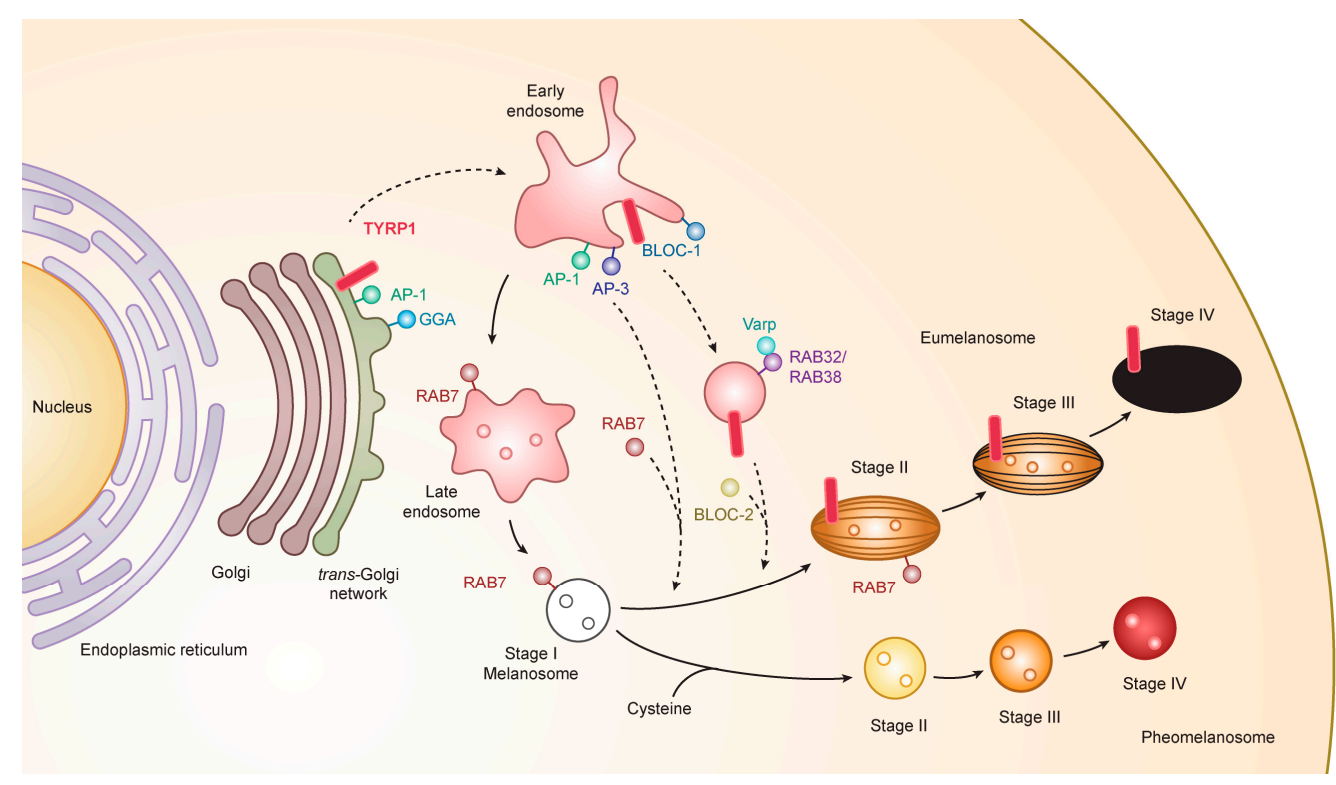

Figure 2. Melanogenesis and intracellular trafficking for melanosome biosynthesis. MITF turns on melanogenesis by activating transcription of pigment genes such as TYR, TYRP1, DCT, and PMEL which are transported from the trans-Golgi network and incorporated into early/late endosomal compartment to form melanosomes. Melanosomes have four maturation stages characterized by unique shapes and amounts of melanin pigments, i.e., eumelanin and pheomelanin. In the case of TYRP1, AP-1 and GGA play key roles in the sorting process of export from trans-Golgi network via early/late endosomes to stage I melanosomes by two other mechanisms: (i) BLOC-1/RAB32/RAB38/Varp/BLOC-2; (ii) AP-1 or AP-3. RAB7 is required for the stage I melanosome formation and the TYRP1 sorting from early/late endosomes to stage I melanosomes. Abbreviations: AP, adaptor protein; BLOC, biogenesis of lysosome-related organelles complex; GGA, Golgi-localized $\gamma$-ear-containing ADP-ribosylation factor -binding protein. 
In addition to PMEL, several other proteins including OA1 (GPR143), MART1, and SLC45A2 are involved in melanosome biogenesis [46,47]. OA1 (ocular albinism 1) is the G protein-coupled receptor for Dopa and tyrosine. A mutation in OA1 causes ocular albinism. Albinism refers to conditions in which there is little or no pigment synthesis due to various gene mutations. There are two categories of albinism; one is oculocutaneous albinism (OCA), in which pigment synthesis is dysfunctional in the skin, hair, and eyes. The other category is ocular albinism, in which only the eyes are affected [48-50] (Table 1).

\subsection{Roles and Signaling of Tyrosinase and Related Proteins in Melanogenesis}

Melanocyte differentiation is characterized by melanin biosynthesis, a biological property unique to the different types of melanin-forming cells, e.g., melanophores, melanocytes, and their neoplastic counterparts, melanoma cells. Two forms of melanin pigment, i.e., brown-black eumelanin and yellow-red pheomelanin, are produced within melanosomes (Figure 3). Lower vertebrates do not synthesize pheomelanin.

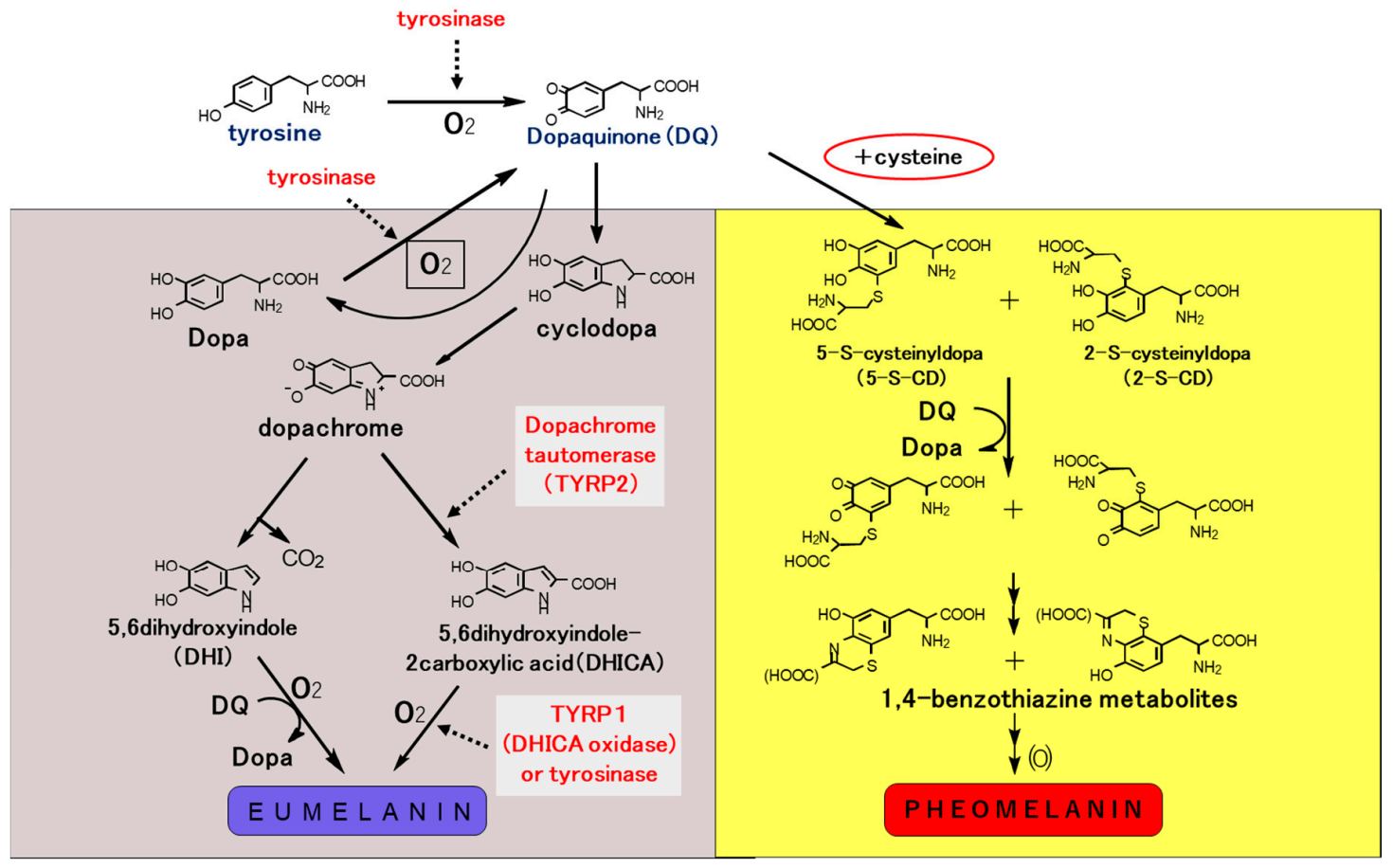

Figure 3. Biosynthetic pathway of eumelanin and pheomelanin. Eumelanin and pheomelanin begin with the common pathway by converting tyrosine to Dopa and subsequently Dopa to dopaquinone. Tyrosinase interacts with two tyrosinase related proteins, TYRP1 and TYRP2 or dopachrome tautomerase (DCT) to form eumelanin pigments. On the other hand, cysteine is incorporated into dopaquinone to form cysteinyldopa which is then converted to benzothiazine metabolites to form pheomelanin pigments. Dopaquinone obtained by tyrosinase oxidation is a highly reactive intermediate, and in the absence of thiol compounds, it undergoes intramolecular cyclization, leading eventually to the production of eumelanin. However, the intervention of thiols, such as cysteine, with this process gives rise to the thiol adducts. Further oxidation of these cysteinyldopa isomers leads to the production of pheomelanin. In reality, most of the melanin pigments present in the hair and skin, and in melanomas may not be homopolymers of a single monomer unit, but rather they are complex heteropolymers made up of both eumelanin and pheomelanin building blocks.

Tyrosinase is the key enzyme that initiates melanin biosynthesis, converting tyrosine to dopa and subsequently Dopa to dopaquinone. Tyrosinase interacts with two tyrosinase-related proteins, TYRP1 and TYRP2 (dopachrome tautomerase, DCT). These three enzymes are membrane-bound 
melanogenic glycoproteins expressed exclusively in melanocytes and melanoma cells. TYRP1 and TYRP2 function only in eumelanin biosynthesis, with TYRP2 catalyzing tautomerization of dopachrome to 5,6-dihydroxyindole-2-carboxylic acid (DHICA), which is converted to eumelanin by TYRP1 (Figure 4).

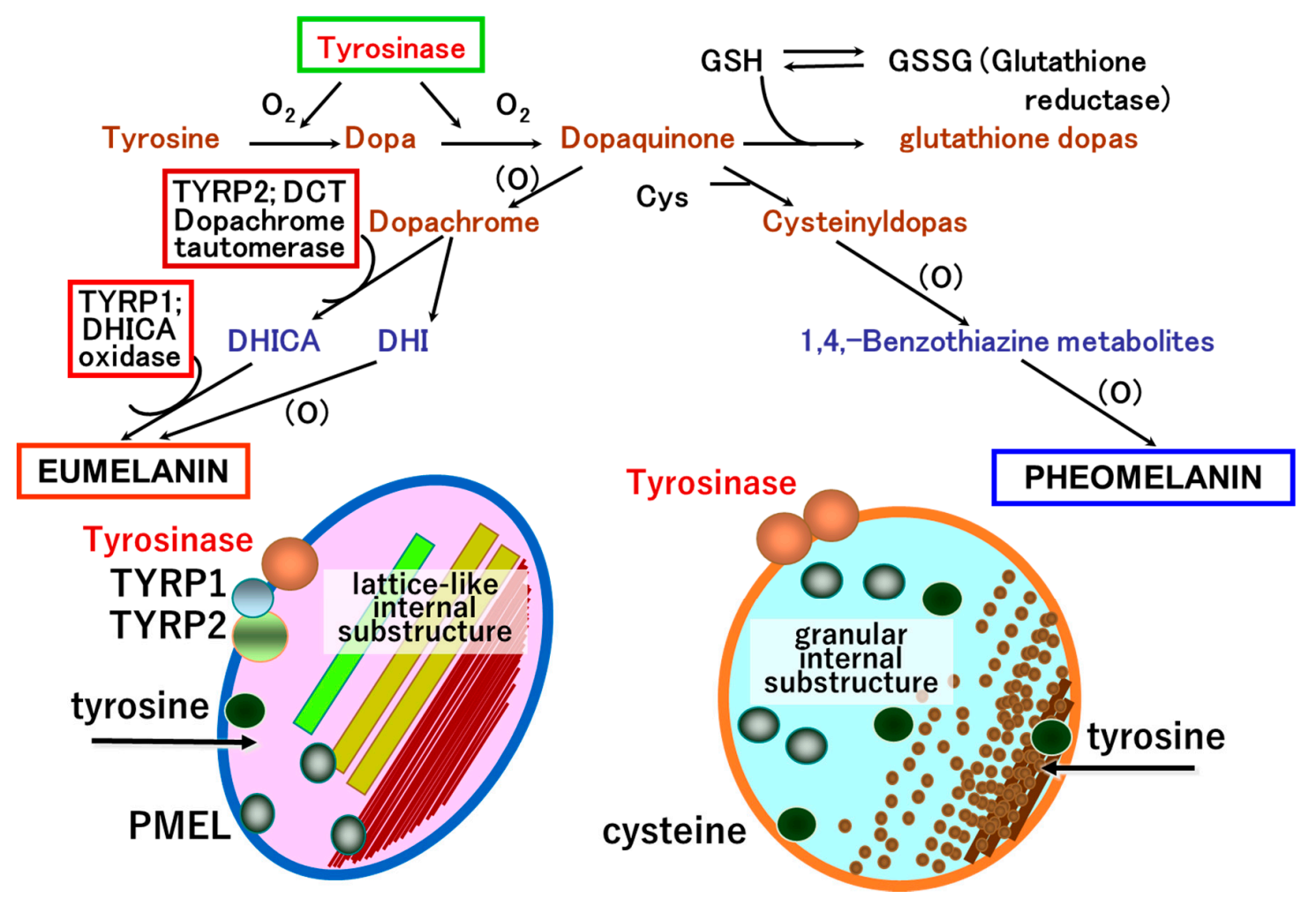

Figure 4. Cascade of eumelanogenesis and pheomelanogenesis. Mature stage IV melanosomes reveal a unique shape. Eumelanosomes become ellipsoidal with specific lattice-like internal structure that is formed by structural matrix protein, PMEL. Pheomelanosomes take oval forms with many internal structures. Both eumelanosomes and pheomelanosomes possess a significant number of microvesicles, which were originally reported as "vesiculoglobular bodies" deriving from the carriers of vesicular transport [41].

Tyrosinase and TYRP1 are similar in structure, having approximately $40 \%$ amino acid homology with a common $\mathrm{NH}_{2}$-terminal signal sequence, a cysteine-rich region, two copper-binding domains, a transmembrane region, and a cytoplasmic tail containing a dileucine motif. Tyrosinase and TYRP1 are post-translationally glycosylated and have mature protein sizes of $65-72$ and $75 \mathrm{kDa}$, respectively. TYRP1 is the most abundant melanosomal protein in melanocytes. While the enzymatic activity of TYRP1 is not fully understood, murine Tyrp1 has activity as a DHICA oxidase, generating indole-5,6-quinone-carboxylic acid, a precursor of eumelanin. TYRP1 forms a stable complex with tyrosinase in the melanosomal membrane and scavenges tyrosinase-mediated oxidative species. Thus, it is likely that TYRP1 stabilizes the melanosomal membrane in melanin biosynthesis.

\subsection{Transport to Melanosomes and Sorting of Tyrosinase and Tyrosinase-Related Proteins}

The generation of melanosomes and synthesis of melanin require multiple sorting events in the biosynthetic and endocytic pathways of melanocytes. These sorting events are highly controlled by several trafficking machineries including the interaction of heterotetrameric adaptors with specific amino acid motifs in the cytoplasmic tail of melanosomal cargo proteins. In order to synthesize melanin, melanogenic enzymes must be delivered into melanosomes. Two transport pathways are involved 
in transporting proteins from early/late endosomes to melanosomes. One pathway is mediated by adaptor-related protein (AP) complexes, mainly AP-3 and AP-1, and the other pathway is mediated by biogenesis of lysosomal organelle complexes 1 and 2 (BLOC-1 and BLOC-2). Many of the genes coding for AP and BLOC subunits are controlled by MITF. AP-3 subunits include both ubiquitous and tissue-specific isoforms and appear to be involved in the transport of tyrosinase from endosomes to melanosomes. Additionally, AP-1 allows the organization of tyrosinase and TYRP1 by employing the microtubule motor protein KIF13A [51,52] (Figure 2).

The other protein complexes involved in the assembly of melanogenic enzymes into melanosomes are the BLOC complexes. BLOC-1 has multiple subunits including BLOC1S1, BLOC1S2, BLOC1S3, BLOC1S5, cappuccino, pallidin, snapin, and dysbindin. Most recently, BLOC1S5, corresponding with the mouse mutation muted, was found to be the responsible gene for Hermansky-Pudlak syndrome type 11 [53]. BLOC-1 allows the delivery of ATP7A, a copper carrier protein that is essential for tyrosinase activity, to melanosomes. Deficiency of BLOC-2, which contains three subunits, leads to the impaired delivery of tyrosinase and TYRP1. BLOC-3 is another complex in this protein family, but its role in melanogenesis is not clear [54,55].

Tyrosinase and TYRP1 are transported from the trans-Golgi network (TGN) to early/late endosomal compartments of stage I melanosomes. The compartments are associated with cation-independent mannose 6-phosphate receptor (CI-M6PR) and regulated by the ADP-ribosylation factor (ARF) [56]. We have studied the mechanism for intracellular trafficking of tyrosinase and TYRP1 proteins. Our preliminary studies indicated that the interaction of tyrosinase with both AP- 1 and AP-3 is likely to be involved in its transport to pre-formed immature stage II melanosomes. AP-3 has been shown to be involved in a transport step from endosomes to melanosomes, but it is unknown which trafficking step AP-1 is responsible for [57]. AP-3 does not interact with TYRP1, but AP-3 mediates tyrosinase trafficking in human melanocytes [58]. TYRP1 is transported exclusively to melanosomes, but not to lysosomes [43]. TYRP1 is shown to be co-localized with AP-1 in the vicinity of the TGN [43,58], suggesting the involvement of AP-1 in proper targeting of TYRP1 to melanosomes. AP- 1 interacts with the cytoplasmic tail of TYRP1 in a yeast three-hybrid assay [57], suggesting that AP-1 interacts with TYRP1 in melanocytes.

A novel family of monomeric clathrin adaptor proteins, Golgi-localized $\gamma$-ear-containing ARF-binding proteins (GGAs), has been shown to regulate clathrin-mediated anterograde transport from the TGN independently of or in concert with AP-1 [58,59]. Three isoforms of GGA proteins (GGA1-3) have been identified [58-60].

\subsection{Novel Functional Motif of TYRP1 in the Early Stage of Melanogenesis}

Mutations of tyrosinase cause oculocutaneous albinism type 1. AP-3 binds the di-leucine motif in the cytoplasmic domain of tyrosinase [61]. Primary melanocytes from a patient with Hermansky-Pudlak syndrome type 2, which have a mutation in an AP-3 subunit (Table 1), were compared with normal melanocytes to show that AP-3 transfers tyrosinase (but not TYRP1) to melanosomes [62]. Both AP-1 and AP-3 sort tyrosinase from endosomes to melanosomes [57]. In our studies, it was found that the asn-gln-pro-leu-leu-thr sequence of the TYRP1 cytoplasmic domain is required for proper transportation of TYRP1 to melanosomes [63]. PI3K is necessary for TYRP1 transportation [56]. Rab7 plays a key role in transport of tyrosinase and TYRP1 from endosomes to melanosomes $[6,8,64]$. In addition, Rab7 is involved in the maturation of the melanosomal matrix protein PMEL [9]. It would be interesting to explore if TYRP1 may contribute in the development of a melanoma-targeted therapy or drug delivery system, in as much as melanogenesis and TYRP1 are biological properties highly elevated and uniquely expressed in melanocytes and melanoma cells. 
Table 1. Human hypomelanotic disorders associated with certain genetic defects.

\begin{tabular}{|c|c|c|c|}
\hline Human Disease & $\begin{array}{l}\text { Major Clinical } \\
\text { Features }\end{array}$ & Mutated Gene & Gene Action in Humans \\
\hline \multicolumn{4}{|l|}{ GENERALIZED } \\
\hline $\begin{array}{l}\text { Oculocutaneous } \\
\text { albinism type } 1\end{array}$ & $\begin{array}{l}\text { Hypopigmentation, } \\
\text { nystagmus }\end{array}$ & $T Y R$ & $\begin{array}{l}\text { Key enzyme for melanin } \\
\text { biosynthesis }\end{array}$ \\
\hline $\begin{array}{l}\text { Oculocutaneous } \\
\text { albinism type } 2\end{array}$ & & OCA2 & Melanosome biogenesis and size \\
\hline $\begin{array}{l}\text { Oculocutaneous } \\
\text { albinism type } 3\end{array}$ & & TYRP1 & $\begin{array}{l}\text { Melanosomal enzyme; stabilizing } \\
\text { factor }\end{array}$ \\
\hline $\begin{array}{l}\text { Oculocutaneous } \\
\text { albinism type } 4\end{array}$ & & SLC45A2 & $\begin{array}{c}\text { Solute transporter; previously } \\
\text { named MATP }\end{array}$ \\
\hline $\begin{array}{l}\text { Oculocutaneous } \\
\text { albinism type } 5\end{array}$ & & $(4 q 24)$ & Responsible gene is not known \\
\hline $\begin{array}{l}\text { Oculocutaneous } \\
\text { albinism type } 6\end{array}$ & & SLC24A5 & $\begin{array}{l}\text { Predominant sodium-calcium } \\
\text { exchanger in melanocytes }\end{array}$ \\
\hline $\begin{array}{l}\text { Oculocutaneous } \\
\text { albinism type } 7\end{array}$ & & $L R M D A$ & $\begin{array}{c}\text { Required for melanocyte } \\
\text { differentiation; previously named } \\
\text { C10orf11 }\end{array}$ \\
\hline $\begin{array}{l}\text { Ocular albinism } \\
\text { type } 1\end{array}$ & $\begin{array}{l}\text { Iris hypopigmentation, } \\
\text { nystagmus }\end{array}$ & GPR143 & $\begin{array}{l}\text { G protein-coupled receptor } \\
\text { localized at melanosomal } \\
\text { membrane }\end{array}$ \\
\hline $\begin{array}{l}\text { Hermansky-Pudlak } \\
\text { syndrome type } 1\end{array}$ & $\begin{array}{l}\text { Hypopigmentation, } \\
\text { bleeding, } \\
\text { immunodeficiency }\end{array}$ & HPS1 & $\begin{array}{l}\text { Component of BLOC-3, which acts } \\
\text { as a guanine exchange factor; } \\
\text { organelle biogenesis and size }\end{array}$ \\
\hline $\begin{array}{l}\text { Hermansky-Pudlak } \\
\text { syndrome type } 2\end{array}$ & & AP3B1 & $\begin{array}{c}\beta 1 \text { subunit of } \mathrm{AP}-3 \text { complex; } \\
\text { organelle protein routing }\end{array}$ \\
\hline $\begin{array}{l}\text { Hermansky-Pudlak } \\
\text { syndrome type } 3\end{array}$ & & HPS3 & $\begin{array}{c}\text { BLOC-2 subunit } 1 \text {; organelle } \\
\text { biogenesis }\end{array}$ \\
\hline $\begin{array}{l}\text { Hermansky-Pudlak } \\
\text { syndrome type } 4\end{array}$ & & HPS4 & $\begin{array}{c}\text { Component of BLOC-3; organelle } \\
\text { biogenesis and size }\end{array}$ \\
\hline $\begin{array}{l}\text { Hermansky-Pudlak } \\
\text { syndrome type } 5\end{array}$ & & HPS5 & $\begin{array}{c}\text { BLOC-2 subunit 2; organelle } \\
\text { biogenesis }\end{array}$ \\
\hline $\begin{array}{l}\text { Hermansky-Pudlak } \\
\text { syndrome type } 6\end{array}$ & & HPS6 & $\begin{array}{l}\text { BLOC-2 subunit 3; organelle } \\
\text { biogenesis }\end{array}$ \\
\hline $\begin{array}{l}\text { Hermansky-Pudlak } \\
\text { syndrome type } 7\end{array}$ & & DTNBP1 & Dysbindin, component of BLOC- 1 \\
\hline $\begin{array}{l}\text { Hermansky-Pudlak } \\
\text { syndrome type } 8\end{array}$ & & BLOC1S3 & BLOC- 1 subunit 3 \\
\hline $\begin{array}{l}\text { Hermansky-Pudlak } \\
\text { syndrome type } 9\end{array}$ & & BLOC1S6 & BLOC-1 subunit 6 \\
\hline $\begin{array}{l}\text { Hermansky-Pudlak } \\
\text { syndrome type } 10\end{array}$ & & AP3D1 & $\begin{array}{c}\delta 1 \text { subunit of AP- } 3 \text { complex; } \\
\text { organelle protein routing }\end{array}$ \\
\hline $\begin{array}{l}\text { Hermansky-Pudlak } \\
\text { syndrome type } 11\end{array}$ & & BLOC1S5 & BLOC- 1 subunit 5 \\
\hline $\begin{array}{l}\text { Chediak-Higashi } \\
\text { syndrome }\end{array}$ & $\begin{array}{l}\text { Hypopigmentation, } \\
\text { immunodeficiency }\end{array}$ & LYST & $\begin{array}{l}\text { Protein required for sorting } \\
\text { endosomal resident proteins into } \\
\text { late multivesicular endosomes }\end{array}$ \\
\hline $\begin{array}{l}\text { Griscelli syndrome } \\
\text { type } 1\end{array}$ & $\begin{array}{l}\text { Hypopigmentation, } \\
\text { pancytopenia, } \\
\text { immunologic disorder, } \\
\text { central nervous system } \\
\text { abnormalities }\end{array}$ & MYO5A & $\begin{array}{l}\text { Melanosome transport; myosin } \\
\text { type Va/dilute mice }\end{array}$ \\
\hline
\end{tabular}


Table 1. Cont.

\begin{tabular}{|c|c|c|c|}
\hline Human Disease & $\begin{array}{l}\text { Major Clinical } \\
\text { Features }\end{array}$ & Mutated Gene & Gene Action in Humans \\
\hline $\begin{array}{l}\text { Griscelli syndrome } \\
\text { type } 2\end{array}$ & & $R A B 27 A$ & $\begin{array}{l}\text { Melanosome transport; } \\
\text { RAS-associated protein/ashen } \\
\text { mice }\end{array}$ \\
\hline $\begin{array}{l}\text { Griscelli syndrome } \\
\text { type } 3\end{array}$ & & $M L P H$ & $\begin{array}{l}\text { Melanosome transport; } \\
\text { melanophilin/leaden mice }\end{array}$ \\
\hline Phenylketonuria & $\begin{array}{c}\text { Phenylalanine } \\
\text { hydroxylase deficiency }\end{array}$ & PAH & Phenylalanine hydroxylase \\
\hline $\begin{array}{l}\text { Charcot-Marie-Tooth } \\
\text { disease type } 4 \mathrm{~J}\end{array}$ & $\begin{array}{l}\text { Pale skin, alopecia, } \\
\text { clumped melanosomes, } \\
\text { immune effects }\end{array}$ & FIG4 & $\begin{array}{l}\text { Phosphatidyl-inositol } \\
\text { 3,5-bisphosphate 5-phosphatase; } \\
\text { aberrant early melanosome } \\
\text { architecture }\end{array}$ \\
\hline Menkes disease & $\begin{array}{l}\text { Copper transport } \\
\text { disorders, kinky hair }\end{array}$ & ATP7A & $\begin{array}{l}\text { ATPase, copper-transporting } \alpha \\
\text { polypeptide }\end{array}$ \\
\hline Wilson disease & $\begin{array}{l}\text { Copper transport } \\
\text { disorders, kinky hair }\end{array}$ & AТР7B & $\begin{array}{l}\text { ATPase, copper-transporting } \beta \\
\text { polypeptide }\end{array}$ \\
\hline Cystinosis & $\begin{array}{l}\text { Blond hair, multiple } \\
\text { organ dysfunctions }\end{array}$ & CTNS & $\begin{array}{c}\text { Cystinosin, cysteine } / \mathrm{H}^{+} \\
\text {symporter, which exports cysteine } \\
\text { out of lysosomes }\end{array}$ \\
\hline $\begin{array}{c}\text { Tietz } \\
\text { albinism-deafness } \\
\text { syndrome }\end{array}$ & $\begin{array}{l}\text { Congenital profound } \\
\text { deafness, generalized } \\
\text { hypopigmentation }\end{array}$ & MITF & $\begin{array}{l}\text { Transcription factor; master } \\
\text { regulator of melanocyte lineage }\end{array}$ \\
\hline \multicolumn{4}{|l|}{ CIRCUMSCRIBED } \\
\hline $\begin{array}{l}\text { Waardenburg } \\
\text { syndrome type } 1 \\
\text { and } 3\end{array}$ & $\begin{array}{l}\text { White forelock, } \\
\text { premature graying, } \\
\text { hearing loss, } \\
\text { heterochromia, other } \\
\text { neural crest defects }\end{array}$ & PAX3 & $\begin{array}{c}\text { Transcription factor; neural tube } \\
\text { development }\end{array}$ \\
\hline $\begin{array}{l}\text { Waardenburg } \\
\text { syndrome type } 2\end{array}$ & & MITF, SNAI2, SOX10 & $\begin{array}{l}\text { Transcription factors; master } \\
\text { regulator of melanocyte lineage } \\
\text { transcription factor }\end{array}$ \\
\hline $\begin{array}{l}\text { Waardenburg } \\
\text { syndrome type } 4\end{array}$ & & $\begin{array}{l}\text { EDNRB, EDN3, } \\
\quad \text { SOX10 }\end{array}$ & $\begin{array}{l}\text { Endothelin receptor B; } \\
\text { melanoblast/neuroblast growth } \\
\text { and differentiation factor; } \\
\text { transcription factor }\end{array}$ \\
\hline Piebaldism & $\begin{array}{l}\text { White spotting, } \\
\text { megacolon, and other } \\
\text { neural crest defects }\end{array}$ & KIT, SNAI2 & $\begin{array}{l}\text { Receptor for SCF; required for } \\
\text { melanoblast survival and homing; } \\
\text { melanocyte lineage transcription } \\
\text { factor }\end{array}$ \\
\hline Tuberous sclerosis & $\begin{array}{l}\text { White macules, } \\
\text { angiofibromas and } \\
\text { Koenen tumors }\end{array}$ & TSC1, TSC2 & $\begin{array}{l}\text { Negative regulators of } \\
\text { PI3K-AKT-MTOR pathway }\end{array}$ \\
\hline Hypomelanosis of Ito & $\begin{array}{l}\text { Hypopigmentation } \\
\text { along Blaschko } \\
\text { lines/neural disorders }\end{array}$ & $\begin{array}{l}\text { Chromosomal } \\
\text { aberration }\end{array}$ & $\begin{array}{l}\text { Somatic mosaicism probably } \\
\text { affecting keratinocytes }\end{array}$ \\
\hline $\begin{array}{l}\text { Incontinentia } \\
\text { pigmenti }\end{array}$ & $\begin{array}{l}\text { White striae along } \\
\text { Blaschko's lines } \\
\text { (stage 4) }\end{array}$ & $I K B K G$ & $\begin{array}{c}\text { Nuclear factor- } \mathrm{kB} \text { essential } \\
\text { modulator/inhibitor of } \kappa \text { light } \\
\text { polypeptide gene enhancer in B } \\
\text { cells, kinase } \gamma\end{array}$ \\
\hline
\end{tabular}




\section{Melanin Pigmentation and Pigment-Type Switching}

\subsection{Coat Color and Melanin Pigmentation}

The two types of melanin pigment, brown-black eumelanin and yellow-red pheomelanin, are produced exclusively by melanocytes and are mixed together regardless of the pigmentary phenotype in humans [68]. The ratio of the two melanin pigments within the melanosome is determined by race and/or specific genetic variations [69]. Black, brown, light brown, and blond hairs differ only in their eumelanin content, while red hair is exceptional in that it contains pheomelanin fourfold greater than light brown and blond hairs [70]. Variations in pigmentation derive mostly from differences in the relative amount of total melanin pigment rather than from the relative ratio of eumelanin and pheomelanin. The basal composition of the mixed eu- and pheo-melanin in an individual does not change dramatically, though external stimuli to melanocytes such as UV irradiation can affect the ratio and content of eumelanin and pheomelanin [70].

On the other hand, many mammals have various patterns of hair coat color that can be changed temporally. Expression of the wild type Agouti gene in mice results in hair with a characteristic color pattern: subapical yellow bands in an otherwise black coat [71]. This black-yellow-black pattern results from a rapid change of melanin synthesis in hair bulb melanocytes, called pigment-type switching. In the beginning of the hair cycle (days 0-4), all hair bulb melanocytes synthesize eumelanin. During days 4-6, they produce pheomelanin in response to agouti stimuli from dermal papilla cells, followed by more eumelanin synthesis. Major regulators of pigment-type switching are the MC1R and agouti proteins. Other modulatory factors such as ATRN and MGRN1 are also involved in this process (Figure 5, Table 2).

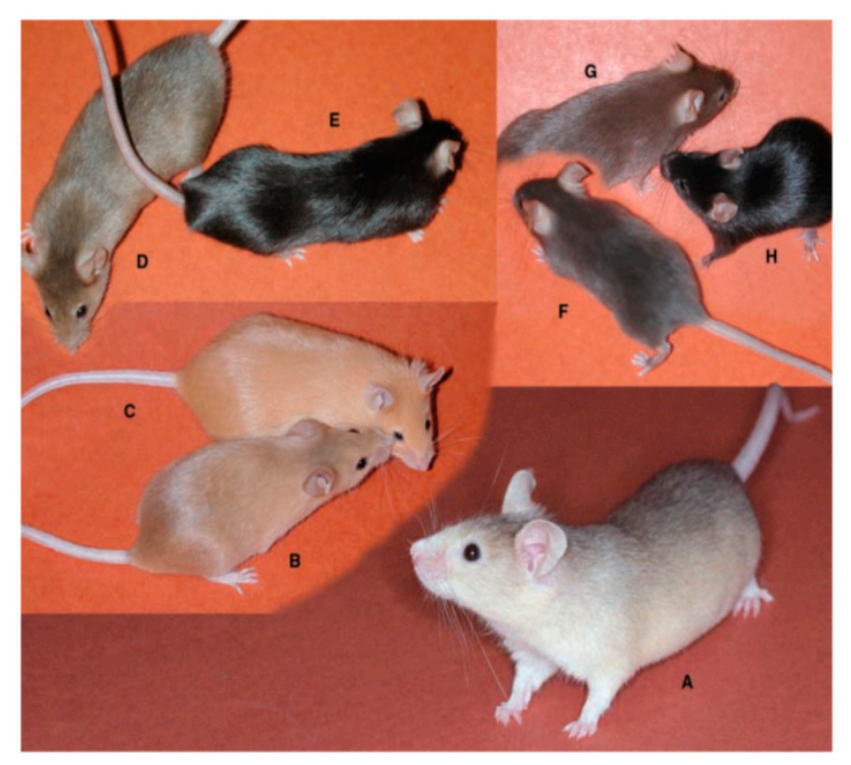

Figure 5. Mouse color mutations. All mice are of strain C57BL/6J except (A). On the C57BL/6J background, the $A^{y / a}$ mouse is clear yellow (C), whereas on the JU/CtLm background it is paler clear yellow (A). (B) $M c 1 r^{e} / M c 1 r^{e}$ (recessive yellow). (D) Ay/a, Atrn ${ }^{m g} / A_{t r n}{ }^{m g}$ (mahogany). (E) a/a, $A t r n^{m g} / A t r n^{m g}$. (F) $D c t^{s l t} / D c t^{s l t}$, slaty. (G) Tyrp $1^{b} / T^{2} r p 1^{b}$, brown. (H) C57BL/6J (a/a, nonagouti), control mouse. Reproduced from reference [72], courtesy of Bennett, D.C. and Lamoreux, M.L. 
Table 2. Comparison of human and murine loci related to pigment-type switching.

\begin{tabular}{|c|c|c|c|}
\hline Human Gene & Mouse Gene (Locus) & Function & Relevant Clinical Condition \\
\hline$A S I P$ & Agouti (a) & Reverse agonist of MC1R & Hair/skin color polymorphism \\
\hline$M C 1 R$ & $\operatorname{Mc1r}(E)$ & $\begin{array}{l}\text { G-protein coupled } \\
\text { receptor } \\
\text { Hormonal regulation }\end{array}$ & $\begin{array}{c}\text { Hair/skin color polymorphism } \\
\text { Susceptibility to UV-induced } \\
\text { damage }\end{array}$ \\
\hline ATRN & $\operatorname{Atrn}(m g)$ & $\begin{array}{l}\text { Modifier of MC1R-agouti } \\
\text { binding }\end{array}$ & $\begin{array}{l}\text { Darker hair (mouse) } \\
\text { Spongiform encephalopathy } \\
\text { (mouse) }\end{array}$ \\
\hline MGRN1 & Mgrn1 (md) & $\begin{array}{l}\text { E3 ubiquitin ligase } \\
\text { Modifier of MC1R } \\
\text { signaling }\end{array}$ & $\begin{array}{l}\text { Darker hair (mouse) } \\
\text { Spongiform encephalopathy } \\
\text { (mouse) } \\
\text { Facial dysmorphology (mouse) } \\
\text { Curled whisker (mouse) }\end{array}$ \\
\hline
\end{tabular}

\subsection{Mechanism of Pigment-Type Switching}

Two major loci have a central role for pigment-type switching in mice. One is the extension (E) locus encoding the Mc1r gene and the other is the Agouti (a) locus encoding the Agouti gene (Table 2) [71]. There are dozens of mouse strains with coat color mutations in one or both of these loci. For example, sombre $\left(M c 1 r^{E-s o} / M c 1 r^{+}, M c 1 r^{E-s o} / M c 1 r^{E-s o}\right)$ and nonagouti $(a / a)$ mice have black hairs in the whole body, while recessive yellow $\left(M c 1 r^{e} / M c 1 r^{e}\right)$ and lethal yellow $\left(A^{y} / a\right)$ have yellow hairs (Figure 5) [71]. These mutant mice have contributed to the study of the mechanism of pigment-type switching.

Among the 5 melanocortin receptors, only MC1R is expressed mainly in melanocytes [73-75]. It is a G-protein-coupled receptor, with its physiologic agonist ligands being $\alpha$-MSH and adrenocorticotrophic hormone (ACTH) secreted from various cells including keratinocytes and melanocytes. UV light-irradiated keratinocytes and melanocytes produce $\alpha$-MSH and ACTH from the POMC gene [76]. $\alpha-\mathrm{MSH} / \mathrm{ACTH}$ acts as a paracrine/autocrine mediator and binds to MC1R on the cell surface of melanocytes. MC1R also has high constitutive activity, which means that MC1R can signal without binding to an agonist $[77,78]$. The constitutive activity is enhanced upon paracrine/autocrine activation by $\alpha-\mathrm{MSH}$ or ACTH. Activated MC1R signals through Gs proteins and adenylate cyclase and increases intracellular cAMP, which results in the activation of protein kinase A (PKA). A catalytic subunit of PKA translocates to the nucleus to phosphorylate CREB transcription factors, which increase the transcription of MITF (Figure 6). MITF increases the expression of tyrosinase, TYRP1 and TYRP2 (DCT), and the synthesis of eumelanin [75]. Moreover, MITF contributes to the control of the distribution of melanosomes and their transfer to keratinocytes by regulating the expression of RAB27A $[79,80]$.

Agouti, another ligand of MC1R, works as a reverse agonist while $\alpha-\mathrm{MSH}$ acts as an agonist. Agouti, which consists of a 109 amino acid soluble peptide and a 22 amino acid signal peptide, is secreted by dermal papilla cells in the hair follicles. The C-terminus of agouti competitively antagonizes $\alpha-\mathrm{MSH}$ at MC1R and suppresses the basal activity of MC1R [81]. Inhibition of MC1R activity results in the downregulation of cAMP-PKA-CREB-MITF signaling and low tyrosinase activity. Melanocytes with low tyrosinase activity preferentially produce pheomelanin in the presence of cysteine and form a yellow band in an agouti hair [68]. Although the C-terminal domain of agouti inhibits canonical cAMP-dependent signaling, the N-terminal side of Agouti is hypothesized to be involved in cAMP-independent MC1R signaling, affecting melanocyte growth and differentiation (Figure 6) [78].

Numerous agouti alleles and mutations exist in mice, resulting in a variety of coat colors. In lethal yellow mice $\left(A^{y} / a\right)$, due to an upstream gene deletion, agouti is ubiquitously expressed under control of the housekeeping Raly promotor, which results in yellow coat color and obesity. In nonagouti mice $(a / a)$, an intragenic large insertion abolishes the expression of Agouti, which results in a black coat 
color without agouti banding. In humans, the association of the agouti signaling protein (ASIP) gene, an orthologue of mouse Agouti, with skin/hair pigmentation has been shown [82,83].

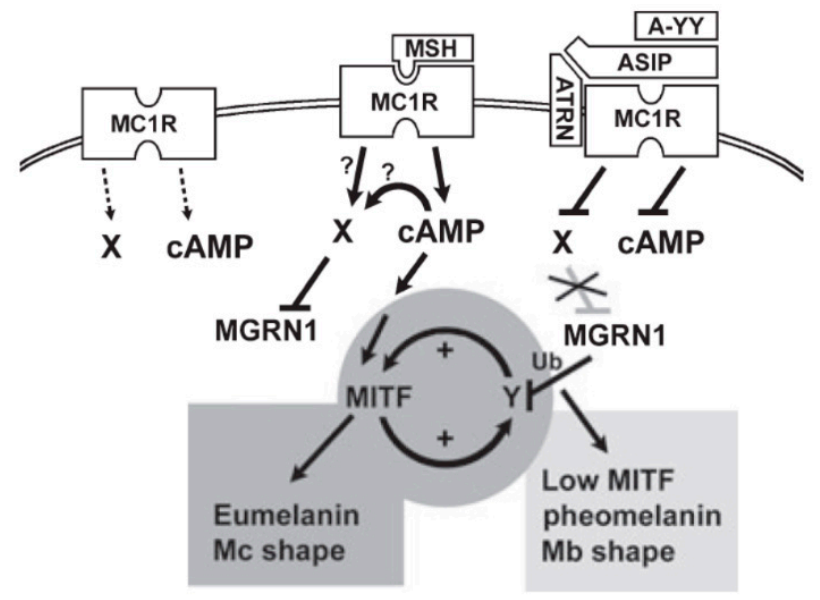

Figure 6. Model of pigment-type switching controlled by dual signaling from MC1R. ASIP, agouti-signaling protein (agouti protein); A-YY (ASIP-YY), a synthetic C-terminal fragment of agouti protein; Mc, melanocyte; $\mathrm{Mb}$, melanoblast; $\mathrm{Ub}$, ubiquitinylation. Melanocortin-1 receptor (MC1R) is shown with some basal activity (left). MC1R can activate both CAMP and another signaling pathway $X$. Activation of $X$ may be cAMP-dependent or -independent. Agouti protein can antagonize cAMP signaling through its C-terminus (or as ASIP-YY) and can independently antagonize $\mathrm{X}$ signaling through its N-terminus and through ATRN and MGRN1, resulting in inhibition of eumelanogenesis and enhancement of pheomelanogenesis. To explain the activation of eumelanogenesis by cAMP, yet persistence of eumelanogenesis when the cAMP signal is withdrawn, a positive feedback loop was suggested. MGRN1 may break the loop by ubiquitinating and destabilizing one component $\mathrm{Y}$. This would lead to a less differentiated state with low MITF activity, permissive for pheomelanogenesis. Reproduced from reference [78].

\subsection{Accessory Factors of Signaling Through MC1R}

Mahogany $(m g)$ is a recessive allele in mice (Table 2, Figure 5D). The gene of the $m g$ locus is attractin (Atrn) and its human orthologue is the ATRN gene [84]. In an agouti background (A/-), homozygous loss-of-function alleles $\left(A t r n^{m g} / A t r n^{m g}\right)$ reduce or eliminate pheomelanin synthesis and result in spongy degeneration and hypomyelination in the central nervous system [85]. ATRN is expressed in melanocytes as a type I membrane protein. Homozygous $\mathrm{Atrn}^{m g}$ darkens the yellow hair of $A^{y} / a$ mice (Figure 5D), but does not affect the yellow hair of $M c 1 r^{e} / M c 1 r^{e}$ mice [71]. This indicates that ATRN functions downstream of agouti and upstream of MC1R. As ATRN binds to the N-terminal domain of agouti, it is hypothesized that ATRN stabilizes agouti-MC1R binding and is involved in cAMP-independent signaling elicited by agouti [78]. ATRN is also expressed in the brain and testis and has a critical role in normal myelination in the central nervous system (Table 2).

Mahoganoid $(\mathrm{md})$ is also a recessive allele. Mahoganoid mice show a phenotype similar to mahogany but also show facial dysmorphism, curled whiskers, and reduced viability due to mispatterning of the left-right axis during development [71]. The gene of the $m d$ locus is Mahogunin ring finger 1 (Mgrn1), the product of which acts in the cytosol as an E3 ubiquitin ligase. Known targets of ubiquitination by MGRN1 are TSG101, $\alpha$-tubulin, and $\beta$-arrestins [86-88]. TSG101 functions in the sorting of ubiquitinated transmembrane proteins into multivesicular bodies and $\alpha$-tubulin is a component of microtubules that function in cell motility, morphology, intracellular transport, mitosis, and meiosis. However, the roles of TSG101 and $\alpha$-tubulin in pigment synthesis are not known. Recently, it was reported that MGRN1, in the presence of wild-type MC1R, ubiquitinated $\beta$-arrestins, core components of MC1R desensitization [79]. Melanocortin receptors may also be targets of ubiquitination by MGRN1, but inhibition by MGRN1 of the functional coupling of MC1R with the cAMP pathway was independent 
of MC1R ubiquitination [79]. Besides its ubiquitin ligase activity, MGRN1 has the ability to bind to the cytosolic domain of MC1R competitively with G/s and thereby inhibit the MC1R-cAMP signaling [89]. Interestingly, two of four isoforms of MGRN1 have a nuclear localization signal and may provide a pathway for MC1R signaling from the cell surface to the nucleus [89].

In dogs, the $K$ locus dominantly affects hair color independently of the $a$ locus. $K^{B}$ and $k^{y}$ are a dominant black hair and a wild-type yellow hair alleles, respectively [90]. The responsible gene of the $K$ locus is CBD103, of which the human orthologues are the $\beta$-defensin-3 genes DEFB103A and $D E F B 103 B$, known to encode antimicrobial proteins. The wild-type CBD103 gene, which is responsible for the $k^{y}$ phenotype, encodes a secreted protein consisting of a 45 amino acid final polypeptide and a 22 amino acid signal peptide. The $K^{B}$ phenotype is caused by an amino acid deletion in CBD103

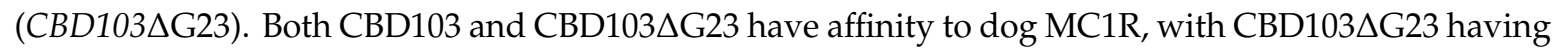
higher affinity. Therefore, $C B D 103$ and $C B D 103 \triangle G 23$ are hypothesized to act as competitive antagonists to agouti protein [91]. In humans, $\beta$-defensin- 3 inhibited $\alpha$-MSH-induced cAMP production, leading to the conclusion that $\beta$-defensin-3 is a neutral antagonist [92,93]. Although it is suggested that $\beta$-defensin-3 is involved in the desensitization of MC1R, the exact role of $\beta$-defensin-3 in regulating human pigmentation needs to be elucidated.

\section{Development of a Novel Therapeutic Approach for Pigmentary Disorders and Malignant Melanoma by Elucidation of the Melanogenesis Cascade}

\subsection{Melanogenesis Elucidation and Therapeutic Approach for Pigmentary Disorders and Malignant Melanoma}

Malignant melanoma of skin is often associated with a fatal problem because it occurs at the highly vascular epidermal-dermal interface, and spreads from the beginning of the disease to any parts of the body more rapidly than any other solid tumor. Currently remarkable progresses have been made in developing various treatment options for metastatic melanoma. The options include checkpoint inhibition immunotherapies, e.g., anticytotoxic T lymphocyte antigen 4 (CTLA-4), anti-programmed death 1 (PD-1), molecular-targeted therapies, e.g., BRAF and MEK inhibitors, and gene directed enzyme prodrug therapy using, for example, engineered mesenchymal and neural stem cells. These treatments have shown not only high response rates, but also side effects and limitations [94,95].

Elucidation of biological properties unique to melanocytes may, however, provide an additional novel approach to overcome the difficult challenge of treating pigmentary disorders and advanced-stage melanoma. This approach is based on chemical modification of tyrosinase substrates, in particular sulfur-amine analogue of tyrosine, N-acetyl-4-S-cysteaminylphenol (NAcCAP) and N-propionyl-4-S-cysteaminylphenol (NPrCAP). NAcCAP and NPrCAP were selected because they were most efficient tyrosinase substrates that we have tested [96].

In addition, our previous studies showed that NAcCAP was selectively delivered to B16 melanoma cells in an in vivo syngeneic mouse model. We also showed a decrease of lung metastases after treatment with NAcCAP [97]. NPrCAP was also found to elicit apoptotic cell death selectively and efficiently in melanocytes and melanoma cells through production of highly reactive free radicals by reacting with tyrosinase [98]. Accordingly, our past studies have indicated that derivatives of tyrosinase substrates can provide a novel drug delivery system and selective cytocidal activity to melanocytes and melanoma cells, hence providing the basis for the development of a new therapeutic approach for pigmentary disorders such as for facial hyperpigmentation (melasma) [96] (Figure 7). However, these synthetic compounds alone may not be sufficient to control the growth of melanoma cells, indicating the necessity for an additional strategy to enhance our melanogenesis-targeting melanoma therapy. 

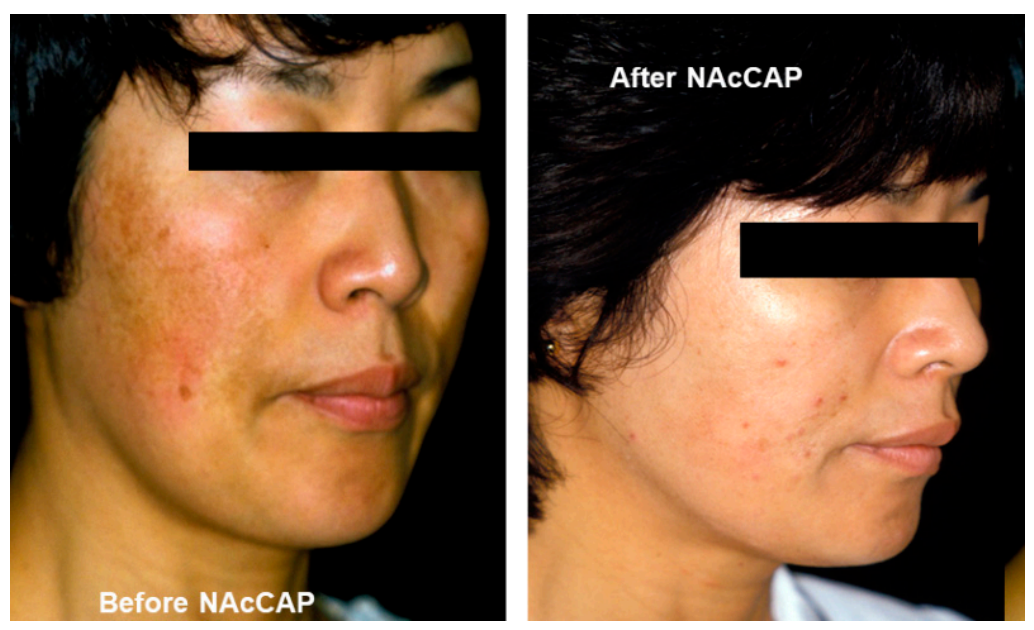

Figure 7. Depigmenting effect of $N$-acetyl-4-S-cysteaminylphenol (NAcCAP). Marked depigmentation of facial pigmentation in a melasma patient after daily topical application of NAcCAP ointment [96].

\subsection{Melanogenesis-Targeted Melanoma Treatment Based on Chemotherapy and Thermo-Immunotherapy}

Recently, thermal-induced anti-tumor immunotherapy utilizing magnetic nanoparticles has been applied to a number of malignant tumors [99]. Hyperthermia produces not only heat-mediated cell death but also an immune reaction due to the generation of heat shock proteins (HSPs). HSP expression induced by hyperthermia has been shown to be involved in tumor immunity. However, magnetic nanoparticles alone do not have homing ability to the targeted lesions; hence, a more direct approach is required. Conjugation of targeting materials, such as antibodies or aptamers, to the surface of the nanoparticles has been attempted to improve the delivery system. Considering the above, it was thought that NPrCAP could be a targeting candidate suitable for conjugation with the nanoparticles, due to its unique properties such as small molecular weight $(\mathrm{MW}=225.31)$, targeting effect and cytotoxic ability specific to melanoma cells. Based on these findings, extensive efforts have been made to develop a novel melanoma-targeted chemo-thermo-immunotherapy (CTI therapy).

As the initial step, several forms of NPrCAP conjugated with magnetite nanoparticles were synthesized. Figure 8 shows the conjugation of magnetites and NPrCAP.

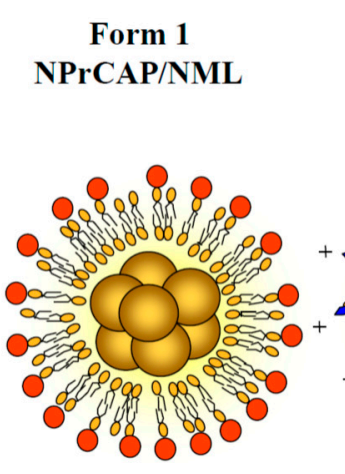

\section{Form 2 NPrCAP/CML}

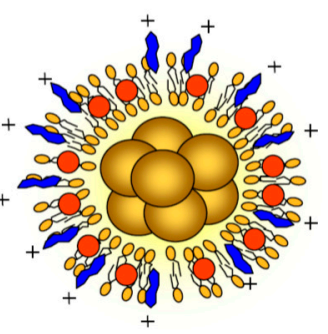

Form 3

NPrCAP/M

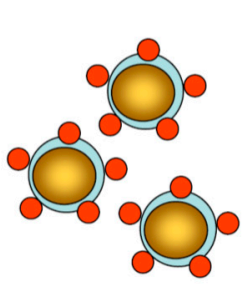

Form 4

NPrCAP/PEG/M

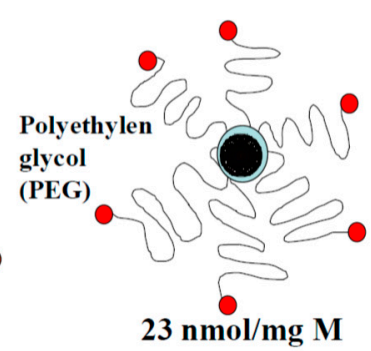

Figure 8. Synthesis of $N$-propionyl-4-S-cysteaminylphenol/magnetite nanoparticles. Several forms of $N$-propionyl-4-S-cysteaminylphenol (NPrCAP)/magnetite (M) nanoparticles conjugates have been synthesized. Form 1: NPrCAP is conjugated on the surface of neutral magnetic liposome particles (NML). Form 2: NPrCAP is embedded in cationic magnetic liposome particles (CML). Form 3: NPrCAP is directly conjugated with magnetite. Form 4: NPrCAP is conjugated with magnetite by polyethylene glycol (PEG). 
It was found that the direct conjugate of NPrCAP with magnetite nanoparticles (NPrCAP/M) is preferentially incorporated into melanoma cell lines compared with magnetite nanoparticles alone [100]. This preferential uptake was not observed in non-melanoma tumor cell lines. We also demonstrated selective delivery and accumulation of NPrCAP/M in the in vivo mouse model. Two cell lines, B16 melanoma cells and RMA lymphoma cells, were inoculated subcutaneously and separately into the lateral flanks. Fourteen days after intraperitoneal (i.p.) administration, NPrCAP/M was found to have been delivered into melanoma cells, but not into lymphoma cells. Electron microscopic examination revealed NPrCAP/M nanoparticles aggregated in melanosomal compartments in the melanoma cells (Figure 9). NPrCAP/M appeared to be selectively aggregated on the cell surface of melanoma cells through a still unknown surface receptor and then incorporated into early and late endosomes of melanoma cells by the vesicular transport system. The conjugates were then incorporated into the melanosomal compartment as the stage I melanosomes derived from late endosome-related organelles, to which tyrosinase was also transported from the trans-Golgi network by vesicular transport (Figure 2). Magnetite nanoparticles (NPrCAP/M) that selectively targeted melanoma cells and accumulated in melanosomal compartments through the selective drug delivery property of NPrCAP were expected to elicit a highly efficient thermal reaction (a thermotherapy effect) after exposure to alternative magnetic field (AMF) irradiation [101]. It was also expected that NPrCAP, because of its heat resistance and stability, can also work as a chemotherapy agent during this "heat shock" process.

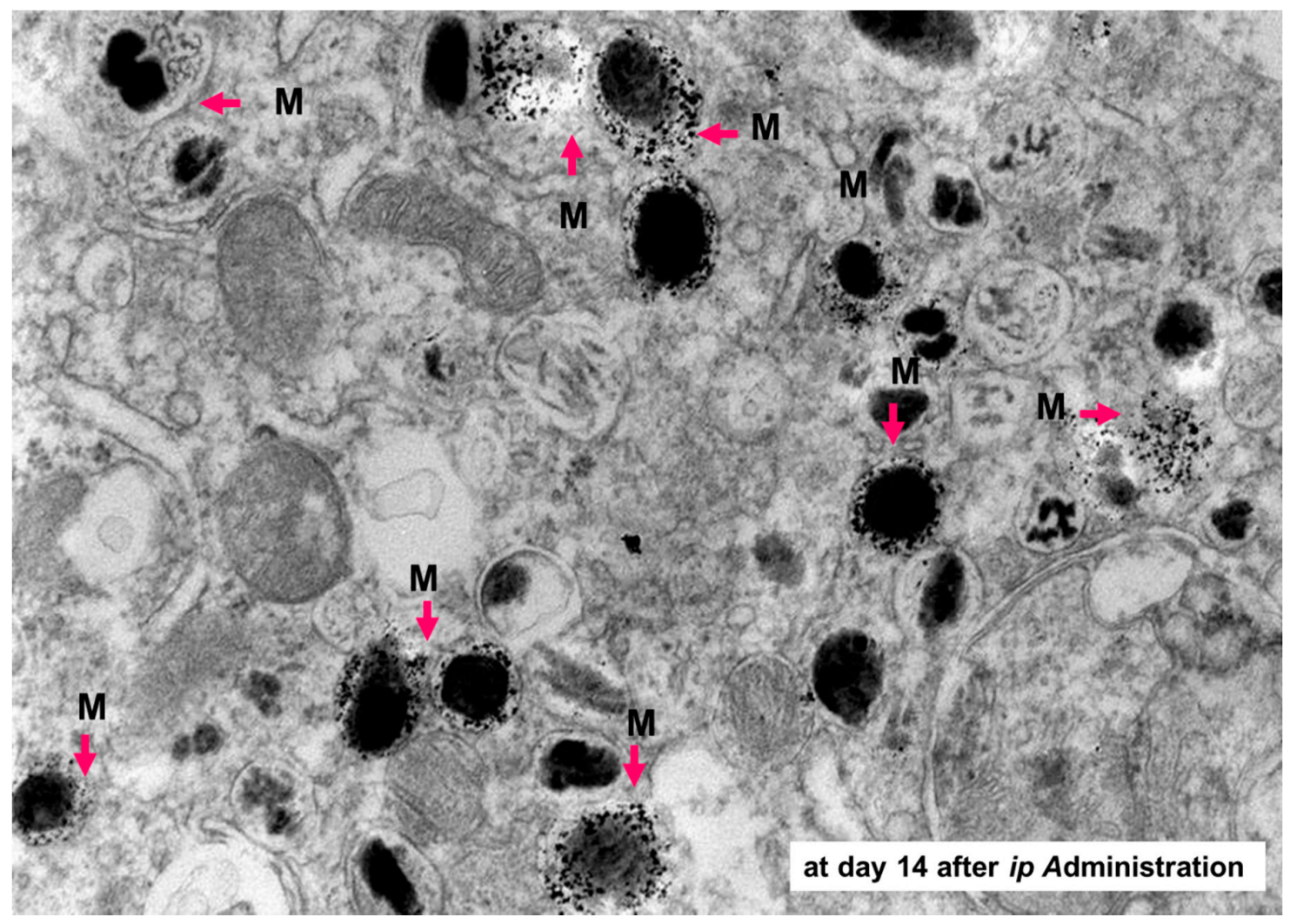

Figure 9. Aggregation of NPrCAP/M in melanosomes of B16 melanoma cells. The electron microscopic examination shows selective delivery of NPrCAP/M into melanosomes 14 days after intraperitoneal administration. M, magnetite.

\subsection{Development of Therapeutic Protocol for Melanoma Chemo-Thermo-Immunotherapy}

In order to further improve the CTI strategy, thermal immunotherapy protocols employed for other types of cancers [101] were tested and modified. In our animal study, B16 melanoma cells were inoculated subcutaneously into flanks on one side of mice and the growing melanoma masses were 
treated with CTI or control therapies. After treatment, the tumors were excised and the mice were rechallenged with inoculation of B16 cells into the opposite side flank, in order to assess the development of acquired tumor immunity [102]. The best anti-tumor therapeutic effect was obtained in a protocol in which direct intratumoral injection of NPrCAP/M was immediately followed by hyperthermia at $43^{\circ} \mathrm{C}$ for $30 \mathrm{~min}$ and the procedure was repeated every other day for a total of 3 treatments. In the mice treated with this protocol, the most significant growth inhibition of both the primarily inoculated melanoma cells and the re-challenge melanoma cells was observed. In the histopathological sections, tumor necrosis was prominent and a significant number of inflammatory cells including $\mathrm{CD} 4^{+}$and $\mathrm{CD} 8^{+} \mathrm{T}$ cells were infiltrated in and around both primary treated tumors and re-inoculated tumors. Interestingly, control mice treated with only NPrCAP/M or NPrCAP, without hyperthermia, also exhibited, to some extent, growth inhibition of the re-challenged melanoma cells [103]. It was speculated that NPrCAP that remained in surviving melanoma cells after hyperthermia may provide additional acquired tumor immunity by a pathway different from hyperthermia-induced tumor immunity.

\subsection{Acquisition of Anti-Melanoma Immunity by CTI Therapy}

In our further efforts to clarify the mechanism of the hyperthermia-mediated immunity acquisition after the treatment with $\mathrm{NPrCAP} / \mathrm{M}$, it was found that $\mathrm{NPrCAP} / \mathrm{M}$ with $\mathrm{AMF}$ irradiation induced increased expression of heat shock protein 72 (HSP72) and non-apoptotic cell death of melanoma cells [104]. HSP72 was also shown to be released extracellularly. In addition, CD8 ${ }^{+} \mathrm{T}$ cells were found to respond to lysates of melanoma cells treated with NPrCAP/M and AMF irradiation, and this reaction was abolished after removal of HSPs by adding anti-HSP antibody. In another mouse melanoma model to analyze the immune response of T cells induced by the CTI therapy [105], an increased level of $\mathrm{CD}^{+} \mathrm{T}$ cells was observed in swollen regional tumor-infiltrating lymph nodes (TIL) at day 14 . The $\mathrm{T}$ cell receptor repertoire was restricted in TIL and $\mathrm{V} \beta 11^{+} \mathrm{T}$ cells were predominant. These findings suggested that NPrCAP/M with AMF irradiation induced an immune response through HSP, and that specific $\mathrm{T}$ cells responded to the treatment. The tumor infiltrating $\mathrm{CD} 8^{+} \mathrm{T}$ cells were found to recognize a TYRP2-derived peptide.

\subsection{Preliminary study of CTI therapy in Advanced Melanoma Patients}

Based on the animal experiments, a preliminary human clinical trial of CTI therapy has been carried out for advanced melanoma patients (Figure 10). However, this preliminary clinical trial used NPrCAP/PEG/M, in which polyethylene glycol (PEG) was employed to conjugate NPrCAP with magnetite nanoparticles (Figure 8). NPrCAP/PEG/M conjugates were chemically stable, did not lose biological properties, and could be filtered and easily produced in large quantities.

A stage IV patient who had multiple skin metastases showed marked regression of other distant skin metastases and survived for 30 months. The patient died of brain metastasis. Another stage III patient also showed marked regression of regional lymph node metastases and survived for 32 months. Primarily treated skin metastases were totally excised after three rounds of the CTI therapy. The histopathological finding showed infiltration of lymphocytes and macrophages in and around the necrotic tumor tissue [12]. 


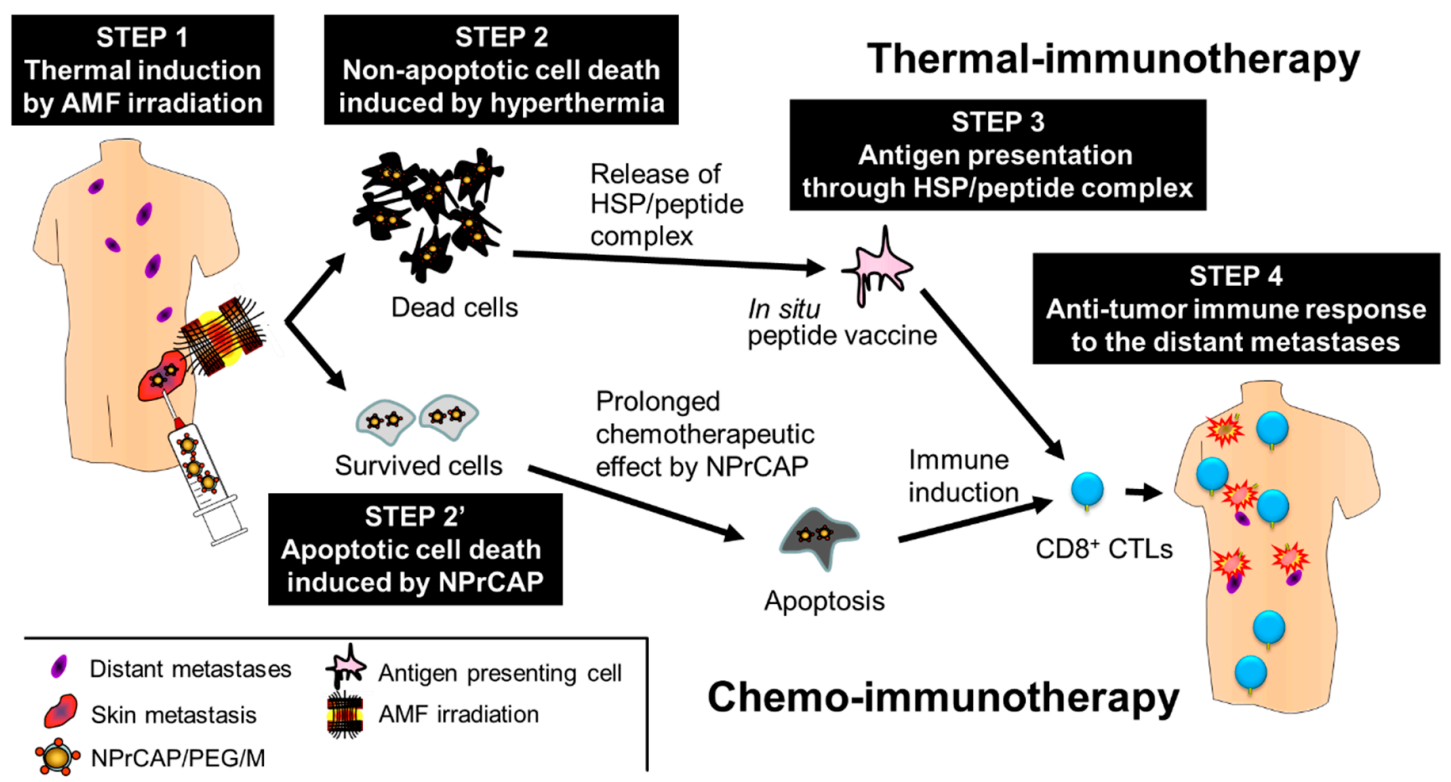

Figure 10. Protocol and mechanism of CTI therapy for melanoma patients in the advanced stage. STEP 1: NPrCAP/PEG/M is injected directly into the target lesion (a skin metastasis on the body surface), followed by AMF irradiation to induce intratumoral hyperthermia at $43^{\circ} \mathrm{C}$ for $30 \mathrm{~min}$. STEP 2: Non-apoptotic cell death is induced in the majority of melanoma cells by hyperthermia. STEP 2': Melanoma cells surviving from the hyperthermia treatment undergo apoptotic cell death through the chemotherapeutic effect of NPrCAP. STEP 3: HSPs and antigenic peptides released from dead cells are taken up by antigen-presenting cells. STEP 4: Anti-tumor immunity acquired through hyperthermia or unknown effects of NPrCAP induces migration of $\mathrm{CD}^{+} \mathrm{T}$ cells to kill other metastases.

\section{Ethics Approval}

All clinical melanoma subjects gave their informed consent for inclusion before they participate in the clinical study. The study was conducted in accordance with the Declaration of Helsinki, and the protocol was approved by the institutional review board of Sapporo Medical University, Japan (No. 18-67).

\section{Conclusions}

As knowledge of melanin biosynthesis increases, new entities of pigmentation disorders will be identified. New therapeutic modalities for pigmentation disorders will also be developed by selectively targeting the melanogenesis cascade at different levels, thereby enabling enhancement or reduction of pigmentation in an aimed fashion with minimum side effects. The melanogenesis cascade may also be utilized to develop a novel approach for better management of hyperpigmentation disorders of the skin and malignant neoplasia of melanocytes. Our new approach of developing CTI therapy for malignant melanoma by elucidation of the melanogenesis cascade is introduced.

Author Contributions: This article is provided by following specific contribution. Writing-original draft preparation of individual sections, T.H., T.K., A.K., J.O.; writing-review and editing of entire sections, K.J.; supervision, H.S., H.U. All authors have read and agreed to the published version of the manuscript.

Funding: The experimental studies presented in this article as supported by a Health and Labor Sciences Research Grant-in-Aid (H21-Nano-006) for Research on Advanced Medical Technology from the Ministry of Health, Labor and Welfare of Japan to K.J. and by JSPS KAKENHI grant numbers JP20790808 and JP23770233 from the Japan Society for the Promotion of Science to T.H.

Conflicts of Interest: The authors declare that they have no conflict of interest. The funders had no role in the design of the study; in the collection, analyses, or interpretation of data; in the writing of the manuscript; or in the decision to publish the results. 


\section{Abbreviations}

\begin{tabular}{|c|c|}
\hline $\mathrm{ACTH}$ & adrenocorticotrophic hormone \\
\hline AMF & alternative magnetic field \\
\hline $\mathrm{AP}$ & adaptor-related protein \\
\hline $\mathrm{ARF}$ & ADP-ribosylation factor \\
\hline ASIP & agouti signaling protein \\
\hline ATRN & attractin \\
\hline cAMP & cyclic adenosine monophosphate \\
\hline CML & cationic magnetic liposome particles \\
\hline CI-M6PR & cation-independent mannose 6-phosphate receptor \\
\hline CRE & cAMP response element \\
\hline CREB & CRE-binding protein \\
\hline CRTC & CREB-regulated transcriptional coactivator \\
\hline CTI & chemo-thermo-immuno \\
\hline DCT & dopachrome tautomerase \\
\hline EMU & epidermal melanin unit \\
\hline GGA & Golgi-localized $\gamma$-ear-containing ADP-ribosylation factor-binding protein \\
\hline HSP & heat shock protein \\
\hline ILV & intralumenal vesicles \\
\hline i.p. & intraperitoneal \\
\hline M & magnetite \\
\hline MC1R & melanocortin 1 receptor \\
\hline MITF & microphthalmia-associated transcription factor \\
\hline $\mathrm{MSH}$ & melanocyte-stimulating hormone \\
\hline MW & molecular weight \\
\hline NAcCAP & $N$-acetyl-4-S-cysteaminylphenol \\
\hline NPrCAP & $N$-propionyl-4-S-cysteaminylphenol \\
\hline NML & neutral magnetic liposome particles \\
\hline OCA & oculocutaneous albinism \\
\hline PEG & polyethylene glycol \\
\hline PI3K & phosphoinositide-3 kinase \\
\hline PKA & protein kinase $\mathrm{A}$ \\
\hline POMC & proopiomelanocortin \\
\hline SIK & salt-inducible kinase \\
\hline TGN & trans-Golgi network \\
\hline TIL & tumor-infiltrating lymph nodes \\
\hline TYRP & tyrosinase-related protein \\
\hline
\end{tabular}

\section{References}

1. Jimbow, K.; Prota, G.; Quevedo, W.C.; Fitzpatrick, T.B. Biology of Melanocytes. In Fitzpatrick's Dermatology in General Medicine, 5th ed.; Freedberg, I.M., Eisen, A.Z., Wolff, E., Austen, K.F., Goldsmith, L.A., Katz, S.I., Fitzpatrick, T.B., Eds.; McGraw-Hill: New York, NY, USA, 1998; pp. 192-220.

2. Kawakami, A.; Fisher, D.E. The master role of microphthalmia-associated transcription factor in melanocyte and melanoma biology. Lab. Investig. 2017, 97, 649-656. [CrossRef] [PubMed]

3. Toyofuku, K.; Wada, I.; Hirosaki, K.; Park, J.S.; Hori, Y.; Jimbow, K. Promotion of tyrosinase folding in Cos 7 cells by calnexin. J. Biochem. 1999, 125, 82-89. [CrossRef] [PubMed]

4. Jimbow, K.; Park, J.S.; Kato, F.; Hirosaki, K.; Toyofuku, K.; Hua, C.; Yamashita, T. Assembly, target-signaling and intracellular transport of tyrosinase gene family protein in the initial stage of melanosome biogenesis. Pigment Cell Res. 2000, 13, 222-229. [CrossRef] [PubMed]

5. Kamada, A.; Nagaya, H.; Tamura, T.; Kinjo, M.; Jin, H.Y.; Yamashita, T.; Jimbow, K.; Kanoh, H.; Wada, I. Regulation of immature protein dynamics in the endoplasmic reticulum. J. Biol. Chem. 2004, 279, 21533-21542. [CrossRef] [PubMed] 
6. Gomez, P.F.; Luo, D.; Hirosaki, K.; Shinoda, K.; Yamashita, T.; Suzuki, J.; Otsu, K.; Ishikawa, K.; Jimbow, K. Identification of Rab7 as a melanosome-associated protein involved in the intracellular transport of tyrosinase-related protein 1. J. Investig. Dermatol. 2001, 117, 81-90. [CrossRef] [PubMed]

7. Riley, P.A. Melanin. Int. J. Biochem. Cell Biol. 1997, 29, 1235-1239. [CrossRef]

8. Hirosaki, K.; Yamashita, T.; Wada, I.; Jin, H.Y.; Jimbow, K. Tyrosinase and tyrosinase-related protein 1 require Rab7 for their intracellular transport. J. Investig. Dermatol. 2002, 119, 475-480. [CrossRef]

9. Kawakami, A.; Sakane, F.; Imai, S.; Yasuda, S.; Kai, M.; Kanoh, H.; Jin, H.Y.; Hirosaki, K.; Yamashita, T.; Fisher, D.E.; et al. Rab7 regulates maturation of melanosomal matrix protein gp100/Pmel17/Silv. J. Investig. Dermatol. 2008, 128, 143-150. [CrossRef]

10. Prota, G. Regulatory mechanisms of melanogenesis: Beyond the tyrosinase concept. J. Investig. Dermatol. 1993, 100, 156S-161S. [CrossRef]

11. Simon, J.D.; Peles, D.; Wakamatsu, K.; Ito, S. Current challenges in understanding melanogenesis: Bridging chemistry, biological control, morphology, and function. Pigment Cell Melanoma Res. 2009, 22, 563-579. [CrossRef]

12. Jimbow, K.; Takada, T.; Osai, Y.; Thomas, P.D.; Sato, M.; Sato, A.; Kamiya, T.; Ono, I.; Tamura, Y.; Sato, N.; et al. Melanogenesis exploitation and melanoma nanomedicine; Utilization of melanogenesis substrate, NPrCAP for exploiting melanoma-targeting drug and its conjunction magnetite nanoparticles for developing melanoma chemo-thermo-immunotherapy. Open Conf. Proc. J. 2011, 2, 5-16. [CrossRef]

13. Kawakami, A.; Fisher, D.E. Key discoveries in melanocyte development. J. Investig. Dermatol. 2011, 131, E2-E4. [CrossRef] [PubMed]

14. Adameyko, I.; Lallemend, F.; Aquino, J.B.; Pereira, J.A.; Topilko, P.; Müller, T.; Fritz, N.; Beljajeva, A.; Mochii, M.; Liste, I.; et al. Schwann cell precursors from nerve innervation are a cellular origin of melanocytes in skin. Cell 2009, 139, 366-379. [CrossRef] [PubMed]

15. Adameyko, I.; Lallemend, F.; Furlan, A.; Zinin, N.; Aranda, S.; Kitambi, S.S.; Blanchart, A.; Favaro, R.; Nicolis, S.; Lübke, M.; et al. Sox2 and Mitf cross-regulatory interactions consolidate progenitor and melanocyte lineages in the cranial neural crest. Development 2012, 139, 397-410. [CrossRef]

16. Steel, K.P.; Davidson, D.R.; Jackson, I.J. TRP-2/DT, a new early melanoblast marker, shows that steel growth factor (c-kit ligand) is a survival factor. Development 1992, 115, 1111-1119.

17. Wehrle-Haller, B.; Weston, J.A. Soluble and cell-bound forms of steel factor activity play distinct roles in melanocyte precursor dispersal and survival on the lateral neural crest migration pathway. Development 1995, 121, 731-742.

18. Shin, M.K.; Levorse, J.M.; Ingram, R.S.; Tilghman, S.M. The temporal requirement for endothelin receptor-B signalling during neural crest development. Nature 1999, 402, 496-501. [CrossRef]

19. Nishimura, E.K.; Jordan, S.A.; Oshima, H.; Yoshida, H.; Osawa, M.; Moriyama, M.; Jackson, I.J.; Barrandon, Y.; Miyachi, Y.; Nishikawa, S. Dominant role of the niche in melanocyte stem-cell fate determination. Nature 2002, 416, 854-860. [CrossRef]

20. Nishimura, E.K.; Granter, S.R.; Fisher, D.E. Mechanisms of hair graying: Incomplete melanocyte stem cell maintenance in the niche. Science 2005, 307, 720-724. [CrossRef]

21. Inomata, K.; Aoto, T.; Binh, N.T.; Okamoto, N.; Tanimura, S.; Wakayama, T.; Iseki, S.; Hara, E.; Masunaga, T.; Shimizu, H.; et al. Genotoxic stress abrogates renewal of melanocyte stem cells by triggering their differentiation. Cell 2009, 137, 1088-1099. [CrossRef]

22. Zhang, B.; Ma, S.; Rachmin, I.; He, M.; Baral, P.; Choi, S.; Gonçalves, W.A.; Shwartz, Y.; Fast, E.M.; Su, Y.; et al. Hyperactivation of sympathetic nerves drives depletion of melanocyte stem cells. Nature 2020, 577, 676-681. [CrossRef]

23. Hertwig, P. Neue Mutationen und Kopplungsgruppen bei der Hausmaus. Z. Induct. Abstammungs-Vererbungsl. 1942, 80, 220-246.

24. Hodgkinson, C.A.; Moore, K.J.; Nakayama, A.; Steingrímsson, E.; Copeland, N.G.; Jenkins, N.A.; Arnheiter, H. Mutations at the mouse microphthalmia locus are associated with defects in a gene encoding a novel basic-helix-loop-helix-zipper protein. Cell 1993, 74, 395-404. [CrossRef]

25. Steingrímsson, E.; Moore, K.J.; Lamoreux, M.L.; Ferré-D’Amaré, A.R.; Burley, S.K.; Zimring, D.C.; Skow, L.C.; Hodgkinson, C.A.; Arnheiter, H.; Copeland, N.G.; et al. Molecular basis of mouse microphthalmia (mi) mutations helps explain their developmental and phenotypic consequences. Nat. Genet. 1994, 8, 256-263. [CrossRef] 
26. Tassabehji, M.; Newton, V.E.; Read, A.P. Waardenburg syndrome type 2 caused by mutations in the human microphthalmia (MITF) gene. Nat. Genet. 1994, 8, 251-255. [CrossRef]

27. Hemesath, T.J.; Steingrímsson, E.; McGill, G.; Hansen, M.J.; Vaught, J.; Hodgkinson, C.A.; Arnheiter, H.; Copeland, N.G.; Jenkins, N.A.; Fisher, D.E. Microphthalmia, a critical factor in melanocyte development, defines a discrete transcription factor family. Genes Dev. 1994, 28, 179-183. [CrossRef]

28. Hemesath, T.J.; Price, E.R.; Takemoto, C.; Badalian, T.; Fisher, D.E. MAP kinase links the transcription factor Microphthalmia to c-Kit signalling in melanocytes. Nature 1998, 391, 298-301. [CrossRef]

29. Yasumoto, K.; Yokoyama, K.; Shibata, K.; Tomita, Y.; Shibahara, S. Microphthalmia-associated transcription factor as a regulator for melanocyte-specific transcription of the human tyrosinase gene. Mol. Cell Biol. 1994, 14, 8058-8070. [CrossRef]

30. Bertolotto, C.; Buscà, R.; Abbe, P.; Bille, K.; Aberdam, E.; Ortonne, J.P.; Ballotti, R. Different cis-acting elements are involved in the regulation of TRP1 and TRP2 promoter activities by cyclic AMP: Pivotal role of M boxes (GTCATGTGCT) and of microphthalmia. Mol. Cell. Biol. 1998, 18, 694-702. [CrossRef] [PubMed]

31. Du, J.; Miller, A.J.; Widlund, H.R.; Horstmann, M.A.; Ramaswamy, S.; Fisher, D.E. MLANA/MART1 and SILV/PMEL17/GP100 are transcriptionally regulated by MITF in melanocytes and melanoma. Am. J. Pathol. 2003, 163, 333-343. [CrossRef]

32. Bertolotto, C.; Abbe, P.; Hemesath, T.J.; Bille, K.; Fisher, D.E.; Ortonne, J.P.; Ballotti, R. Microphthalmia gene product as a signal transducer in cAMP-induced differentiation of melanocytes. J. Cell Biol. 1998, 142, 827-835. [CrossRef] [PubMed]

33. Price, E.R.; Horstmann, M.A.; Wells, A.G.; Weilbaecher, K.N.; Takemoto, C.M.; Landis, M.W.; Fisher, D.E. alpha-Melanocyte-stimulating hormone signaling regulates expression of microphthalmia, a gene deficient in Waardenburg syndrome. J. Biol. Chem. 1998, 273, 33042-33047. [CrossRef] [PubMed]

34. Takeda, K.; Yasumoto, K.; Takada, R.; Takada, S.; Watanabe, K.; Udono, T.; Saito, H.; Takahashi, K.; Shibahara, S. Induction of melanocyte-specific microphthalmia-associated transcription factor by Wnt-3a. J. Biol. Chem. 2000, 275, 14013-14016. [CrossRef] [PubMed]

35. Watanabe, A.; Takeda, K.; Ploplis, B.; Tachibana, M. Epistatic relationship between Waardenburg syndrome genes MITF and PAX3. Nat. Genet. 1998, 18, 283-286. [CrossRef] [PubMed]

36. Cui, R.; Widlund, H.R.; Feige, E.; Lin, J.Y.; Wilensky, D.L.; Igras, V.E.; D’Orazio, J.; Fung, C.Y.; Schanbacher, C.F.; Granter, S.R.; et al. Central role of p53 in the suntan response and pathologic hyperpigmentation. Cell 2007, 128, 853-864. [CrossRef]

37. D’Orazio, J.A.; Nobuhisa, T.; Cui, R.; Arya, M.; Spry, M.; Wakamatsu, K.; Igras, V.; Kunisada, T.; Granter, S.R.; Nishimura, E.K.; et al. Topical drug rescue strategy and skin protection based on the role of Mc1r in UV-induced tanning. Nature 2006, 443, 340-344. [CrossRef]

38. Mujahid, N.; Liang, Y.; Murakami, R.; Choi, H.G.; Dobry, A.S.; Wang, J.; Suita, Y.; Weng, Q.Y.; Allouche, J.; Kemeny, L.V.; et al. A UV-Independent Topical Small-Molecule Approach for Melanin Production in Human Skin. Cell Rep. 2017, 19, 2177-2184. [CrossRef]

39. Yun, W.J.; Kim, E.Y.; Park, J.E.; Jo, S.Y.; Bang, S.H.; Chang, E.J.; Chang, S.E. Microtubule-associated protein light chain 3 is involved in melanogenesis via regulation of MITF expression in melanocytes. Sci. Rep. 2016, 6, 19914. [CrossRef]

40. Djehal, A.; Krayem, M.; Najem, A.; Hammoud, H.; Cresteil, T.; Nebigil, C.G.; Wang, D.; Yu, P.; Bentouhami, E.; Ghanem, G.E.; et al. Targeting prohibitin with small molecules to promote melanogenesis and apoptosis in melanoma cells. Eur. J. Med. Chem. 2018, 155, 880-888. [CrossRef]

41. Theos, A.C.; Truschel, S.T.; Raposo, G.; Marks, M.S. The Silver locus product Pmel17/gp100/Silv/ME20: Controversial in name and in function. Pigment Cell Res. 2005, 18, 322-336. [CrossRef]

42. Kushimoto, T.; Basrur, V.; Valencia, J.; Matsunaga, J.; Vieira, W.D.; Ferrans, V.J.; Muller, J.; Appella, E.; Hearing, V.J. A model for melanosome biogenesis based on the purification and analysis of early melanosomes. Proc. Natl. Acad. Sci. USA 2001, 98, 10698-10703. [CrossRef] [PubMed]

43. Raposo, G.; Tenza, D.; Murphy, D.M.; Berson, J.F.; Marks, M.S. Distinct protein sorting and localization to premelanosomes, melanosomes, and lysosomes in pigmented melanocytic cells. J. Cell Biol. 2001, 152, 809-824. [CrossRef] [PubMed]

44. Theos, A.C.; Berson, J.F.; Theos, S.C.; Herman, K.E.; Harper, D.C.; Tenza, D.; Sviderskaya, E.V.; Lamoreux, M.L.; Bennett, D.C.; Raposo, G.; et al. Dual loss of ER export and endocytic signals with altered melanosome morphology in the silver mutation of Pmel17. Mol. Biol. Cell 2006, 17, 3598-3612. [CrossRef] 
45. Leonhardt, R.M.; Vigneron, N.; Rahner, C.; Cresswell, P. Proprotein convertases process PMEL17 during secretion. J. Biol. Chem. 2011, 286, 9321-9337. [CrossRef] [PubMed]

46. Delevoye, C.; Giordano, F.; van Niel, G.; Raposo, G. Biogenesis of melanosome-The chessboard of pigmentation. Med. Sci. 2011, 27, 153-162. [CrossRef]

47. Basrur, V.; Yang, F.; Kushimoto, T.; Higashimoto, Y.; Yasumoto, K.; Valencia, J.; Muller, J.; Vieira, W.D.; Watabe, H.; Shabanowitz, J.; et al. Proteomic analysis of early melanosomes: Identification of novel melanosomal proteins. J. Proteome Res. 2003, 2, 69-79. [CrossRef]

48. Incerti, B.; Cortese, K.; Pizzigoni, A.; Surace, E.M.; Varani, S.; Coppola, M.; Jeffery, G.; Seeliger, M.; Jaissle, G.; Bennett, D.C.; et al. Oa1 knock-out: New insights on the pathogenesis of ocular albinism type 1. Hum. Mol. Genet. 2000, 9, 2781-2788. [CrossRef]

49. Lopez, V.M.; Decatur, C.L.; Stamer, W.D.; Lynch, R.M.; McKay, B.S. L-DOPA is an endogenous ligand for OA1. PLoS Biol. 2008, 6, e236. [CrossRef]

50. Giordano, F.; Bonetti, C.; Surace, E.M.; Marigo, V.; Raposo, G. The ocular albinism type 1 (OA1) G-protein-coupled receptor functions with MART-1 at early stages of melanogenesis to control melanosome identity and composition. Hum. Mol. Genet. 2009, 18, 4530-4545. [CrossRef]

51. Raposo, G.; Marks, M.S. Melanosomes-dark organelles enlighten endosomal membrane transport. Nat. Rev. Mol. Cell Biol. 2007, 8, 786-797. [CrossRef]

52. Sitaram, A.; Marks, M.S. Mechanisms of protein delivery to melanosomes in pigment cells. Physiology 2012, 27, 85-99. [CrossRef]

53. Pennamen, P.; Le, L.; Tingaud-Sequeira, A.; Fiore, M.; Bauters, A.; Van Duong Béatrice, N.; Coste, V.; Bordet, J.C.; Plaisant, C.; Diallo, M.; et al. BLOC1S5 pathogenic variants cause a new type of HermanskyPudlak syndrome. Genet. Med. 2020. [CrossRef] [PubMed]

54. Di Pietro, S.M.; Falcón-Pérez, J.M.; Tenza, D.; Setty, S.R.; Marks, M.S.; Raposo, G.; Dell'Angelica, E.C. BLOC-1 interacts with BLOC-2 and the AP-3 complex to facilitate protein trafficking on endosomes. Mol. Biol. Cell 2006, 17, 4027-4038. [CrossRef] [PubMed]

55. Setty, S.R.; Tenza, D.; Truschel, S.T.; Chou, E.; Sviderskaya, E.V.; Theos, A.C.; Lamoreux, M.L.; Di Pietro, S.M.; Starcevic, M.; Bennett, D.C.; et al. BLOC-1 is required for cargo-specific sorting from vacuolar early endosomes toward lysosome-related organelles. Mol. Biol. Cell 2007, 18, 768-780. [CrossRef]

56. Chen, H.; Salopek, T.G.; Jimbow, K. The role of phosphoinositide 3-kinase in the sorting and transport of newly synthesized tyrosinase-related protein-1 (TRP-1). J. Investig. Dermatol. Symp. Proc. 2001, 6, 105-114. [CrossRef] [PubMed]

57. Theos, A.C.; Tenza, D.; Martina, J.A.; Hurbain, I.; Peden, A.A.; Sviderskaya, E.V.; Stewart, A.; Robinson, M.S.; Bennett, D.C.; Cutler, D.F.; et al. Functions of adaptor protein (AP)-3 and AP-1 in tyrosinase sorting from endosomes to melanosomes. Mol. Biol. Cell 2005, 16, 5356-5372. [CrossRef]

58. Nakayama, K.; Wakatsuki, S. The structure and function of GGAs, the traffic controllers at the TGN sorting crossroads. Cell Struct. Funct. 2003, 28, 431-442. [CrossRef]

59. Boman, A.L. GGA proteins: New players in the sorting game. J. Cell Sci. 2001, 114, 3413-3418.

60. Bonifacino, J.S. The GGA proteins: Adaptors on the move. Nat. Rev. Mol. Cell Biol. 2004, 5, 23-32. [CrossRef]

61. Calvo, P.A.; Frank, D.W.; Bieler, B.M.; Berson, J.F.; Marks, M.S. A cytoplasmic sequence in human tyrosinase defines a second class of di-leucine-based sorting signals for late endosomal and lysosomal delivery. J. Biol. Chem. 1999, 274, 12780-12789. [CrossRef]

62. Huizing, M.; Sarangarajan, R.; Strovel, E.; Zhao, Y.; Gahl, W.A.; Boissy, R.E. AP-3 mediates tyrosinase but not TRP-1 trafficking in human melanocytes. Mol. Biol. Cell 2001, 12, 2075-2085. [CrossRef] [PubMed]

63. Vinayagamoorthy, T.; Dakour, J.; Dixon, W.; Jimbow, K. cDNA-based functional domains of a calnexin-like melanosomal protein, p90. Melanoma Res. 1993, 3, 263-269.

64. Hida, T.; Sohma, H.; Kokai, Y.; Kawakami, A.; Hirosaki, K.; Okura, M.; Tosa, N.; Yamashita, T.; Jimbow, K. Rab7 is a critical mediator in vesicular transport of tyrosinase-related protein 1 in melanocytes. J. Dermatol. 2011, 38, 432-441. [CrossRef]

65. Yamaguchi, Y.; Hearing, V.J. Melanocytes and their diseases. Cold Spring Harb. Perspect. Med. 2014, 4, a017046. [CrossRef] [PubMed]

66. Jimbow, K.; Quevedo, W.C., Jr.; Fitzpatrick, T.B.; Szabo, G. Some aspects of melanin biology; 1950-1975. J. Investig. Dermatol. 1976, 67, 721-789. [CrossRef] [PubMed] 
67. Fitzpatrick, T.B.; Jimbow, K.; Donaldson, D.D. Dominant oculocutaneous albinism. Br. J. Dermatol. 1975, 91, 23. [CrossRef]

68. Ito, S.; Wakamatsu, K. Chemistry of mixed melanogenesis-pivotal roles of dopaquinone. Photochem. Photobiol. 2008, 84, 582-592. [CrossRef] [PubMed]

69. Wakamatsu, K.; Kavanagh, R.; Kadekaro, A.L.; Terzieva, S.; Sturm, R.A.; Leachman, S.; Abdel-Malek, Z.; Ito, S. Diversity of pigmentation in cultured human melanocytes is due to differences in the type as well as quantity of melanin. Pigment Cell Res. 2006, 19, 154-162. [CrossRef]

70. Ito, S.; Wakamatsu, K. Quantitative analysis of eumelanin and pheomelanin in humans, mice, and other animals: A comparative review. Pigment Cell Res. 2003, 16, 523-531. [CrossRef] [PubMed]

71. Silvers, W.K. The Coat Colors of Mice: A Model for Mammalian Gene Action and Interaction; Springer: New York, NY, USA, 1979. Available online: http://www.informatics.jax.org/wksilvers/index.shtml (accessed on 4 July 2020).

72. Bennett, D.C.; Lamoreux, M.L. The color loci of mice-a genetic century. Pigment Cell Res. 2003, 16, 333-344. [CrossRef]

73. Mountjoy, K.G.; Robbins, L.S.; Mortrud, M.T.; Cone, R.D. The cloning of a family of genes that encode the melanocortin receptors. Science 1992, 257, 1248-1251. [CrossRef] [PubMed]

74. Chhajlani, V.; Wikberg, J.E. Molecular cloning and expression of the human melanocyte stimulating hormone receptor cDNA. FEBS Lett. 1992, 309, 417-420. [CrossRef]

75. García-Borrón, J.C.; Abdel-Malek, Z.; Jiménez-Cervantes, C. MC1R, the cAMP pathway, and the response to solar UV: Extending the horizon beyond pigmentation. Pigment Cell Melanoma Res. 2014, 27, 699-720. [CrossRef] [PubMed]

76. Chakraborty, A.K.; Funasaka, Y.; Slominski, A.; Ermak, G.; Hwang, J.; Pawelek, J.M.; Ichihashi, M. Production and release of proopiomelanocortin (POMC) derived peptides by human melanocytes and keratinocytes in culture: Regulation by ultraviolet B. Biochim. Biophys. Acta 1996, 1313, 130-138. [CrossRef]

77. Slominski, A.; Plonka, P.M.; Pisarchik, A.; Smart, J.L.; Tolle, V.; Wortsman, J.; Low, M.J. Preservation of eumelanin hair pigmentation in proopiomelanocortin-deficient mice on a nonagouti (a/a) genetic background. Endocrinology 2005, 146, 1245-1253. [CrossRef]

78. Hida, T.; Wakamatsu, K.; Sviderskaya, E.V.; Donkin, A.J.; Montoliu, L.; Lynn Lamoreux, M.; Yu, B.; Millhauser, G.L.; Ito, S.; Barsh, G.S.; et al. Agouti protein, mahogunin, and attractin in pheomelanogenesis and melanoblast-like alteration of melanocytes: A cAMP-independent pathway. Pigment Cell Melanoma Res. 2009, 22, 623-634. [CrossRef]

79. Herraiz, C.; Garcia-Borron, J.C.; Jiménez-Cervantes, C.; Olivares, C. MC1R signaling. Intracellular partners and pathophysiological implications. Biochim. Biophys. Acta Mol. Basis Dis. 2017, 1863, 2448-2461. [CrossRef]

80. Chiaverini, C.; Beuret, L.; Flori, E.; Busca, R.; Abbe, P.; Bille, K.; Bahadoran, P.; Ortonne, J.P.; Bertolotto, C.; Ballotti, R. Microphthalmia-associated transcription factor regulates RAB27A gene expression and controls melanosome transport. J. Biol. Chem. 2008, 283, 12635-12642. [CrossRef]

81. Ollmann, M.M.; Lamoreux, M.L.; Wilson, B.D.; Barsh, G.S. Interaction of Agouti protein with the melanocortin 1 receptor in vitro and in vivo. Genes Dev. 1998, 12, 316-330. [CrossRef]

82. Sulem, P.; Gudbjartsson, D.F.; Stacey, S.N.; Helgason, A.; Rafnar, T.; Jakobsdottir, M.; Steinberg, S.; Gudjonsson, S.A.; Palsson, A.; Thorleifsson, G.; et al. Two newly identified genetic determinants of pigmentation in Europeans. Nat. Genet. 2008, 40, 835-837. [CrossRef]

83. Liu, F.; Visser, M.; Duffy, D.L.; Hysi, P.G.; Jacobs, L.C.; Lao, O.; Zhong, K.; Walsh, S.; Chaitanya, L.; Wollstein, A.; et al. Genetics of skin color variation in Europeans: Genome-wide association studies with functional follow-up. Hum. Genet. 2015, 134, 823-835. [CrossRef] [PubMed]

84. Gunn, T.M.; Miller, K.A.; He, L.; Hyman, R.W.; Davis, R.W.; Azarani, A.; Schlossman, S.F.; Duke-Cohan, J.S.; Barsh, G.S. The mouse mahogany locus encodes a transmembrane form of human attractin. Nature 1999, 398, 152-156. [CrossRef] [PubMed]

85. Gunn, T.M.; Inui, T.; Kitada, K.; Ito, S.; Wakamatsu, K.; He, L.; Bouley, D.M.; Serikawa, T.; Barsh, G.S. Molecular and phenotypic analysis of Attractin mutant mice. Genetics 2001, 158, 1683-1695. [PubMed]

86. Gunn, T.M.; Silvius, D.; Bagher, P.; Sun, K.; Walker, K.K. MGRN1-dependent pigment-type switching requires its ubiquitination activity but not its interaction with TSG101 or NEDD4. Pigment Cell Melanoma Res. 2013, 26, 263-268. [CrossRef] 
87. Srivastava, D.; Chakrabarti, O. Mahogunin-mediated $\alpha$-tubulin ubiquitination via noncanonical K6 linkage regulates microtubule stability and mitotic spindle orientation. Cell Death Dis. 2014, 5, e1064. [CrossRef]

88. Abrisqueta, M.; Olivares, C.; Herraiz, C.; Castejón-Griñán, M.; Sirés-Campos, J.; García-Borrón, J.C.; Jiménez-Cervantes, C. Human melanocortin 1 receptor-mediated ubiquitination of nonvisual arrestins. Role of Mahogunin Ring Finger 1 E3 ligase. Biochim. Biophys. Acta Mol. Cell Res. 2018, 1865, 76-94. [CrossRef]

89. Pérez-Oliva, A.B.; Olivares, C.; Jiménez-Cervantes, C.; García-Borrón, J.C. Mahogunin ring finger-1 (MGRN1) E3 ubiquitin ligase inhibits signaling from melanocortin receptor by competition with Galphas. J. Biol. Chem. 2009, 284, 31714-31725. [CrossRef]

90. Kerns, J.A.; Cargill, E.J.; Clark, L.A.; Candille, S.I.; Berryere, T.G.; Olivier, M.; Lust, G.; Todhunter, R.J.; Schmutz, S.M.; Murphy, K.E.; et al. Linkage and segregation analysis of black and brindle coat color in domestic dogs. Genetics 2007, 176, 1679-1689. [CrossRef]

91. Candille, S.I.; Kaelin, C.B.; Cattanach, B.M.; Yu, B.; Thompson, D.A.; Nix, M.A.; Kerns, J.A.; Schmutz, S.M.; Millhauser, G.L.; Barsh, G.S. A defensin mutation causes black coat color in domestic dogs. Science 2007, 318, 1418-1423. [CrossRef]

92. Swope, V.B.; Jameson, J.A.; McFarland, K.L.; Supp, D.M.; Miller, W.E.; McGraw, D.W.; Patel, M.A.; Nix, M.A.; Millhauser, G.L.; Babcock, G.F.; et al. Defining MC1R regulation in human melanocytes by its agonist $\alpha$-melanocortin and antagonists agouti signaling protein and $\beta$-defensin 3. J. Investig. Dermatol. 2012, 132, 2255-2262. [CrossRef]

93. Nix, M.A.; Kaelin, C.B.; Ta, T.; Weis, A.; Morton, G.J.; Barsh, G.S.; Millhauser, G.L. Molecular and functional analysis of human $\beta$-defensin 3 action at melanocortin receptors. Chem. Biol. 2013, 20, 784-795. [CrossRef] [PubMed]

94. Domingues, B.; Lopes, J.M.; Soares, P.; Populo, H. Melanoma treatment in review. Immunotargets Ther. 2018, 7, 35-49. [CrossRef] [PubMed]

95. Heo, J.R.; Kim, N.H.; Cho, J.; Choi, K.C. Current treatments for advanced melanoma and introduction of a promising novel gene therapy for melanoma. Oncol. Rep. 2016, 36, 1779-1786. [CrossRef] [PubMed]

96. Jimbow, K. N-acetyl-4-S-cysteaminylphenol as a new type of depigmenting agent for the melanoderma of patients with melasma. Arch. Dermatol. 1991, 127, 1528-1534. [CrossRef] [PubMed]

97. Alena, F.; Iwashina, T.; Gili, A.; Jimbow, K. Selective in vivo accumulation of $N$-acetyl-4-S-cysteaminylphenol in B16F10 murine melanoma and enhancement of its in vitro and in vivo antimelanoma effect by combination of buthionine sulfoximine. Cancer Res. 1994, 54, 2661-2666. [PubMed]

98. Minamitsuji, Y.; Toyofuku, K.; Sugiyama, S.; Yamada, K.; Jimbow, K. Sulfur containing tyrosine analogs can cause selective melanocytotoxicity involving tyrosinase-mediated apoptosis. J. Investig. Dermatol. Symp. Proc. 1999, 4, 130-136. [CrossRef] [PubMed]

99. Kobayashi, T.; Kakimi, K.; Nakayama, E.; Jimbow, K. Antitumor immunity by magnetic nanoparticle-mediated hyperthermia. Nanomedicine 2014, 9, 1715-1726. [CrossRef]

100. Sato, M.; Yamashita, T.; Ohkura, M.; Osai, Y.; Sato, A.; Takada, T.; Matsusaka, H.; Ono, I.; Tamura, Y.; Sato, N.; et al. N-propionyl-cysteaminylphenol-magnetite conjugate (NPrCAP/M) is a nanoparticle for the targeted growth suppression of melanoma cells. J. Investig. Dermatol. 2009, 129, 2233-2241. [CrossRef]

101. Algan, O.; Fosmire, H.; Hynynen, K.; Dalkin, B.; Cui, H.; Drach, G.; Stea, B.; Cassady, J.R. External beam radiotherapy and hyperthermia in the treatment of patients with locally advanced prostate carcinoma. Cancer 2000, 89, 399-403. [CrossRef]

102. Takada, T.; Yamashita, T.; Sato, M.; Sato, A.; Ono, I.; Tamura, Y.; Sato, N.; Miyamoto, A.; Ito, A.; Honda, H.; et al. Growth inhibition of re-challenge B16 melanoma transplant by conjugates of melanogenesis substrate and magnetite nanoparticles as the basis for developing melanoma-targeted chemo-thermo-immunotherapy. J. Biomed. Biotechnol. 2009, 2009, 457936. [CrossRef]

103. Ishii-Osai, Y.; Yamashita, T.; Tamura, Y.; Sato, N.; Ito, A.; Honda, H.; Wakamatsu, K.; Ito, S.; Nakayama, E.; Okura, M.; et al. N-propionyl-4-S-cysteaminylphenol induces apoptosis in B16F1 cells and mediates tumor-specific T-cell immune responses in a mouse melanoma model. J. Dermatol. Sci. 2012, 67, 51-60. [CrossRef] [PubMed] 
104. Sato, A.; Tamura, Y.; Sato, N.; Yamashita, T.; Takada, T.; Sato, M.; Osai, Y.; Okura, M.; Ono, I.; Ito, A.; et al. Melanoma-targeted chemo-thermo-immuno (CTI)-therapy using N-propionyl-4-S-cysteaminylphenolmagnetite nanoparticles elicits CTL response via heat shock protein-peptide complex release. Cancer Sci. 2010, 101, 1939-1946. [CrossRef] [PubMed]

105. Ito, A.; Yamaguchi, M.; Okamoto, N.; Sanematsu, Y.; Kawabe, Y.; Wakamatsu, K.; Ito, S.; Honda, H.; Kobayashi, T.; Nakayama, E.; et al. T-cell receptor repertoires of tumor-infiltrating lymphocytes after hyperthermia using functionalized magnetite nanoparticles. Nanomedicine 2013, 8, 891-902. [CrossRef] [PubMed]

(C) 2020 by the authors. Licensee MDPI, Basel, Switzerland. This article is an open access article distributed under the terms and conditions of the Creative Commons Attribution (CC BY) license (http://creativecommons.org/licenses/by/4.0/). 